\title{
A keresztény szabadság jogi és teológiai fogalma
}

\section{RIXER ÁDÁM ${ }^{1}$}

A tanulmány a keresztény szabadság fogalmát kívánja körüljárni, több tudományterület nézöpontjából is megvizsgálva azt. Szükebb célja jogi és teológiai megalapozású munkafogalmak elöállitása, azok föbb elemeinek feltárása, katalogizálása. Mindkét vonatkozásban ismertetjük a hagyományosnak tekintheto" „statikus” megközelitéseket, valamint - s ez adja a valódi újdonságot - a dinamikusabb, folyamatszerüségük révén életközelibb fogalmakat elökészito" felvetéseket, új elemeket is. A jogi fogalom meghatározása során ez egy jogszociológiai megközelitést eredményez, amely a ténylegesen jogként érvényesülö gyakorlatok elmélyültebb vizsgálatára törekszik a különféle jogforrások mechanikus elemzése, kommentálása helyett. A teológiai fogalom esetében pedig a hagyományos szekvenciák ellenében a szabadság dinamikus fogalmának megragadására egy kiteljesedő emberi karakter fejlödési fázisai révén kerül sor. A tanulmány jól mutatja a különféle tudományterületek eredményeinek egymásra gyakorolt hatását, és - szándékai szerint - utat nyit a további kutatásoknak is.

Kulcsszavak: keresztény szabadság, jogi normák, joggyakorlat, Biblia, teológia

\section{The Legal and Theological Notion of Christian Liberty}

This essay focuses on the notion of Christian liberty, examining it from the perspective of severalfields of science. Itconcentrates mainly on the preparation of a legal and also of a theological notion by revealing and cataloguing the main possible elements those notions might consist of. We offer a traditional and also a more dynamic, process-like version related to both aspects. Firstly, the new legal notion of Christian liberty is based on a sociological basis that refers not only to the legal norms / legal decisions but also to the practices of different authorities beyond those legal sources. Secondly, the new theological notion of Christian liberty is shown by referring to the stages of the development of a human being's character. Moreover, this essay properly demonstrates that the results of different sciences may mutually influence each other.

Keywords: Christian liberty, legal norms, legal practices, Bible, theology

1 Tanszékvezető egyetemi tanár, KRE ÁJK Közigazgatási Jogi Tanszék; e-mail: rixer.adam@kre.hu. 


\section{Bevezetés}

A jelen tanulmányban a keresztény szabadság jogi és teológiai fogalmának meghatározására teszünk kísérletet. Tesszük ezt úgy, hogy mindkét vonatkozásban felajánlunk egy stabil, hagyományos megközelítést, illetve egy dinamikusabb, s álláspontunk szerint hasznosabb, teljesebb képet adó munkafogalmat is. Az olvasó bizonnyal felteszi a kérdést, hogy miért nem elegendő egyik vagy másik vizsgálati irány kijelölése, azaz milyen többlettudás remélhető a kettős megközelítéstől? A válasz egyik biztos eleme annak rögzítése, hogy bár a keresztény szabadságnak soha nem lesz úgynevezett szuperfogalma, azaz több tudományterület eredményeit ötvöző tudományos konstrukciója, az egyes területek fogalmi elemei - amint azt látni fogjuk - ma is igen nagy hatást gyakorolnak egymásra, alakítva, befolyásolva egymás definícióit is. Éppen ezért e tanulmány első fejezete egyenesen katalogizálja a téma szempontjából lényegesebb tudományterületeket, felvillantva azok kiindulópontjait, kedves résztémáit, sőt a többi területtel érintkező felületeit is. Így a jogi és teológiai megközelítések mellett a politikatudomány, a szociálpszichológia, a szúken vett vallástudomány keresztény szabadságról alkotott képének kulcskifejezéseit is megjelenítjük - noha a részletes és önálló fejezetben is megjelenő elemzést csupán az első két megközelítés esetében végezzük majd el.

E munka alapozó kutatás; a Biblia és a különféle releváns jogforrások mellett elsősorban a tudományos szakirodalom forrásaira támaszkodik a csoportosítás lehetöségeire koncentrálva, továbbá a csoportképző ismérvek fellelésére, az ezekből adódó következtetésekre és egy fogalmi háló kialakítására törekedve. A jogi típusú példák elsősorban magyarországiak, de ahol a tágabb kontextus is indokolt volt, ott más entitások jogalkotásának, illetve jogalkalmazásának termékei és a nemzetközi szakirodalmi eredmények is megjelennek.

\section{A keresztény szabadság jelenségeit is vizsgáló tudományok}

E fejezetben a teológiai és a jogi szempontokat nem elemezzük, de rögzítjük, hogy amennyiben valaki azt az igencsak nagy terjedelmủ kérdést tenné fel, hogy mi is az a keresztény szabadság, a legpontosabb válaszokat éppen a két terület - azaz a jog és a teológia - képviselőitől remélhetné, tekintve, hogy egyrészt minden más társadalmi jelenséghez hasonlóan a kereszténységgel összefüggő tények is jogi úton egyneműsíthetők a legkönnyebben (azaz a „Mit tehet és mit nem egy keresztény?” kérdésre adott jogi típusú válaszokból is összeállíthatunk egy jól alkalmazható, előzetes definíciót), másrészt nehezen vitatható, hogy az adott vallás alapdokumentuma - esetünkben a teljes Írás (a Biblia) - és annak magyarázatai jelentik a másik fontos, sőt megkerülhetetlen és mindennél pontosabb kiindulópontot. 


\subsection{A keresztény szabadság a politika és a politikatudomány vonzásában}

Elemzésünk első érdemi eleme nem véletlenül a politikai összefüggések vizsgálata: a 20. század egyik keresztény szabadsággal kapcsolatos kulcskérdése az úgynevezett felszabaditási mozgalom dilemmája, annak kérdése tudniillik, hogy a keresztény üzenet mennyiben válhat, alakulhat át politikai cselekvéssé. A politikai megközelítések részleges önállósulása és teológiával való összekeveredése különösen jól érzékeltethető a Katolikus Egyházban lezajlott folyamatokon keresztül.

A keresztény hagyomány századokon át az emberi akarat szabadságával foglalkozott, ezen belül is elsősorban a jó és a rossz közötti választást, a bűnt és annak következményeit vizsgálta, másrészt a kegyelem és a szabad akarat viszonyát elemezte. ${ }^{2}$ A szabadságjogokat előtérbe állító felvilágosodás nyomán azonban - egy hosszabb folyamat eredményeképpen - a Katolikus Egyház is nyitni kezdett a szabadság e világi, társadalmi értelmezése felé, azon értelmezés felé, amely a fennálló társadalmi viszonyokat nem fogadja el rendszerszinten változtathatatlan adottságokként.

„A döntő áttörést a II. Vatikáni Zsinat (1962-1965) hozta meg az Egyház küldetésének újrafogalmazásával. Egyértelművé tették, hogy az Egyház evangelizáló feladata nem csupán a túlvilági üdvösség hirdetésére és a történelemben való megjelenítésére irányul. Törődnie kell az ember evilági boldogulásával is, amint azt XXIII. János pápa már a zsinat meghirdetésekor határozottan kijelentette.

A pápa ezzel kapcsolatban még egy új szempontra hívta fel a figyelmet: az Egyháznak tanulmányoznia kell »az idők jeleit« (Mt 16,3). Az Egyház benne él a történelemben, az evangéliumot nem légüres térben hirdeti. A teológiának meg kell ismernie azt a kort, amelyben benne él, hogy így meg tudja szólítani korának embereit, és sorsközösséget tudjon vállalni velük. Így kapott jelentős szerepet »az idők jelei« fogalom a XX. századi teológiában.”3

A Zsinat befejezésének huszadik évfordulója alkalmából összehívott rendkívüli szinódus utóbb már a Zsinat legfontosabb témái között említi a szegények melletti kiállást: „A II. Vatikáni Zsinat nyomán az Egyház erősebben tudatára ébredt a szegények, az elnyomottak, a peremre szorítottak szolgálatára szóló küldetésének. [...] Az Egyháznak prófétai módon el kell ítélnie a szegénység és az elnyomás minden formáját, és mindenütt védelmeznie és szorgalmaznia kell az emberi személy alapvető és elidegeníthetetlen jogait." ${ }^{\prime}$ A szegényekért való kiállás mozgalmi jelleget öltött, s a gyorsan kiépülő, majd még gyorsabban egymással is konfrontálódó tanításai „felszabadítási teológia" néven váltak ismertté.

2 Lukács László: A keresztény szabadság politikai dimenziói a felszabadítási teológia tükrében. Sapientiana, 7. (2014), 2. 1-31. 1.

3 Uo. 2.

4 Walter Kasper (szerk.): Zukunft aus der Kraft des Konzils. Die ausserordentliche Synode '85. Freiburg, Herder, 1986. 43. Idézi Lukács i. m. (2. lj.) 3. 
A II. rendes püspöki szinódus 1971-ben a papi szolgálat mellett már kifejezetten az „igazságosság a világban” témájával foglalkozott. A szinódus nyomán Igazságosság a világban címmel kiadott dokumentum szerint „[a]hhoz, hogy az Egyház hitelesen szállhasson síkra az igazságosságért, annak meg kell jelennie az Egyházon belül is. Felül kell tehát vizsgálnunk tetteinket, birtoklásunkat, életstílusunkat, az emberi jogokat tiszteletben kell tartani az Egyházon belül is." ${ }^{5}$ A megközelítések egy része azonban már túllépett ezen az álásponton, s például a perui püspöki karnak a szinódusra benyújtott előzetes tervezete már a következőket állította:

„Sok keresztény elköteleződését bátorítja az a teológia, amely a jelen valóságot bünös állapotnak tartja, amely meggátolja Isten terveinek megvalósulását; ez a helyzet a felszabadítás melletti elköteleződésre sarkall, egyszerűen válaszként az Úr hívására, aki arra hívott bennünket, hogy történelmünket magunk alakítsuk. Az Egyház fölfedezi, hogy jelenlétével kikerülhetetlenül belekavarodik a politikába, és hogy az elnyomásnak ebben a helyzetében nem hirdetheti az evangéliumot anélkül, hogy a lelkiismereteket fel ne rázza a felszabadító Krisztus üzenetével.”

$\mathrm{Az}$ e területen megjelenő vélemények evolúciójában - értsd: elvilágiasodásában - még a perui álláspont radikalizmusán is túltett azonban Leonardo Boff ferences teológus (akit 1985-ben el is tiltottak a teológia oktatásától), amikor testvérével, Clodovis Boffal együtt „nyílt levelet” intéztek Joseph Ratzinger bíboroshoz (a későbbi pápához): „Vannak helyzetek, melyekben a keresztény lelkiismeret a társadalmi-gazdasági elnyomó rendszert leleplezni kényszerül, és nem látván más kiutat, végső lehetőségként a jogtalan hatalom megdöntésére fegyvert is fog" - írták. ${ }^{7}$ Ratzinger e kérdéskörről a következőképpen nyilatkozott: „amint már megjegyzetem az erkölcstan válságáról szólva, a »felszabadítás « fó téma Észak-Amerika és Nyugat-Európa gazdag társadalmaiban is: így akarnak megszabadulni a vallásos erkölcstől, és ezzel együtt az ember határaitól. [...] Végül »felszabadítást « keresnek Dél-Amerikában is, mégpedig elsősorban társadalmi, gazdasági és politikai értelemben." Hozzáteszi, hogy e változással párhuzamosan „került a teológiai gondolkodás középpontjába a szótériológia, tehát az üdvösség, a megváltás kérdése, vagy ahogyan ma szívesebben mondják: a felszabaditásé”. Álláspontja szerint:

„Ez abból a tényből származott és származik, hogy a teológia válaszolni akar napjaink világának legégetőbb problémáira, nevezetesen arra, hogy az ember minden erőlködése ellenére sincsen mindenestül megváltva, nem szabad mindenestül, sőt valami egyre növekvő elidegenedésnek a részese. [...] Némely teológia azonban

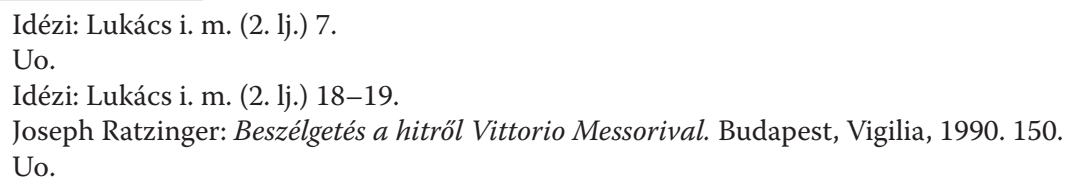


a felszabadítás szekularista programjának hatása alá került; azok a maguk immanens és kizárólagosan földi szempontjaival befolyásolják e teológiákat. Pedig e programok nem látják, és nem is láthatják, hogy keresztény szemszögből a »felszabadítás « mindenekelőtt és főképpen a bün alapvető rabságából való kiszabadulást jelenti, amit a »világ« nem is ért meg, sőt egészen a tagadásáig megy."10

Ratzinger külön utal arra, hogy ez az irány gyakran együtt jár a bibliai szövegek önkényes kezelésével is. ${ }^{11} \mathrm{~A}$ teljesebb kép érdekében meg kell jegyzenünk azt is, hogy az elmúlt bő két évtizedben a felszabaditási teológia újdonsága és kívánatossága jelentősen megkopott a Katolikus Egyházon belül is ${ }^{12}$ - miközben egyébként a szegényekről való gondoskodás más összefüggései kifejezetten előtérbe kerültek.

Összegezve a fent elmondottakat, azt látjuk, hogy a felszabadítási megközelítések jelentős hányadában egy lehetséges következmény (emberi jogok nagyobb tisztelete, garantált érvényesülése, végső soron kivívása) öncéllá válik - leválva a közvetlen bibliai, üdvösséggel összefüggő lelki alapcélokról. Ez volt az a veszélyes irány, amire Jézus tanítványai is ráléptek, amikor egy evilági állam uralkodóját vizionálták Jézusban: csodáit, törekvéseit is eszköznek vélve a hatalom megragadásának folyamatában. Jézus azonban - mellőzve a képletes beszédet - teljesen világossá tette, hogy küzdelme nem a világi hatalom megszerzésére, politikai vagy kifejezetten katonai jellegü csaták megvívására irányul, hanem lelki típusú, adakozásra összpontosító, egyenesen önfeladó életmódot és küldetést jelent. ${ }^{13}$

Bár a fentiekben - érzékeltetendő a politika és a teológia eme igen sajátos öszszekapcsolódását - leginkább a felszabadítási mozgalmak teológiai és egyháztörténeti aspektusait emeltük ki, természetszerüen mindezen jelenségek a szükebben vett politikatudományban is könyvtárnyi irodalomra tettek szert, különösen a dél-amerikai kontinens vonatkozásában. ${ }^{14}$ Egyébiránt izgalmas látni azt is, hogy a teológiai

10 Ratzinger i. m. (8. lj.) 151.

11 Uo. 164.

12 Lánszki Béla: A felszabadítási teológia ideje lejárt? Credo, 5. (1999), 3-4. 69-75.

13 L. Ef 6,12: „Mert mi nem test és vér ellen harcolunk, hanem erők és hatalmak ellen, a sötétség világának urai és a gonoszság lelkei ellen, amelyek a mennyei magasságban vannak” (Magyar Bibliatársulat újfordítású Bibliája [2014]); továbbá, legegyértelműbb példaként: „Akkor odament hozzá Zebedeus fiainak anyja a fiaival együtt, leborult előtte, és kérni akart tőle valamit. Jézus megkérdezte tőle: Mit kívánsz? Ó így felelt: Mondd, hogy melletted üljön az én két fiam a te országodban, az egyik jobb kezed, a másik bal kezed felől. Jézus így válaszolt: Nem tudjátok, mit kértek. Kiihatjátok-e azt a poharat, amelyet én fogok kiinni? Ők így feleltek: Kiihatjuk. Erre ő ezt mondta nekik: Az én poharamat kiisszátok ugyan, de hogy ki üljön jobb és bal kezem felől, azt nem az én dolgom megadni. Azoké lesz, akiknek az én Atyám elkészítette. Amikor ezt meghallotta a többi tíz, megharagudott a két testvérre. De Jézus magához hívta őket, és ezt mondta: Tudjátok, hogy a népek felett zsarnokoskodnak fejedelmeik, és vezetőik hatalmaskodnak rajtuk. De közöttetek ne így legyen, hanem aki naggyá akar lenni közöttetek, az legyen a szolgátok, és aki közöttetek első akar lenni, az legyen a rabszolgátok. Mert az Emberfia sem azért jött, hogy neki szolgáljanak, hanem hogy ő szolgáljon, és életét adja váltságul sokakért.” (Mt 20,20-28) A bibliai részletek lelőhelye: Magyar Bibliatársulat újfordítású Bibliája [2014].

14 Arturo Escobar emeli ki azt a Dél-Amerikában zajló és témánk szempontjából is lényeges kettős 
témájú - részben a szakmai, részben a szélesebb nyilvánosságnak szánt - írások, dokumentumok maguk is milyen intenzitással nyitnak a politikai, a jogi, olykor kifejezetten a demokráciaelméleti összefüggések elemzése felé, egyre nagyobb terjedelemben foglalkozva azokkal, egyúttal csökkentve a teológia és a politikatudomány közti távolságot is...

Azonban eme álláspontok bibliai megalapozottságának vagy egyéb szempontú helytállóságának, tartható mivoltának részletes értékelése nélkül is jól érzékelhető, hogy a felszabadítási logika, azaz a keresztény szabadság politikai dimenziója a közpolitika-formálásnak is egyre hangsúlyosabb, önálló irányává vált. Sőt, amint azt az alábbiakban látni fogjuk, a keresztény szabadság politikai dimenzióinak a magyar közpolitikában is megjelentek - a felszabadítási mozgalmaktól elkülönülő - új elemei.

Orbán Viktor miniszterelnök a 2019-es tusnádfürdői beszédében használta elöször a „keresztény szabadság” kifejezést, mégpedig az alábbi szövegkörnyezetben: „Akárhogy is forgatom és gondolkodom, nem tudok jobb definíciót adni, mint hogy az illiberális politikának az értelme nem más, mint a keresztény szabadság (Christian liberty). A keresztény szabadság és a keresztény szabadság megvédése. Az illiberális, keresztény szabadságért dolgozó politika arra törekszik, hogy megőrizzen mindent, amit a liberálisok elhanyagolnak, elfelejtenek és megvetnek." ${ }^{15}$ A keresztény szabadság fogalmának megjelenése logikailag is jól összekapcsolható azzal, amit Orbán 2018. május 4-i rádiós interjújában - újabb kétharmados választási győzelmét követően - mondott ki először, hogy tudniillik politikai célja immár egy „régi vágású kereszténydemokrácia" felépítése. ${ }^{16}$

A politikai természetű kijelentéseken túl e törekvések egyik kézzelfogható jele a hetedik alaptörvény-módosítás nyomán az (R) cikk új (4) bekezdése („Magyarország alkotmányos önazonosságának és keresztény kultúrájának védelme az állam minden szervének alapvető kötelessége"), amivel kapcsolatban Schanda Balázs jegyzi meg, hogy „[a]z Alaptörvény nem a keresztény vallás, és nem is általában a keresztény kultúra mellett kötelezi el a magyar államot, hanem kifejezetten Magyarország kultúrájának mint keresztény kultúrának a védelemét rendeli el. Az alkotmányozói cél kétségkívül az volt, erőteljesebb hangsúlyt és védelmet adjon az ország kulturális identitásának, azaz többletet a Nemzeti hitvallásban felhívott keresztény örökséghez képest." ${ }^{17}$ Ehhez hozzáteszi azt is, hogy „[a]z Alaptörvény nem intézményesít államvallást, értékelkötelezettséget az állam vallási-világnézeti semlegességét fenntartva teszi hangsúlyosabbá.

folyamatot, amely egyrészt egy 500 éve tartó modernizációs krízisből, másrészt pedig a neoliberális modernizációs modell kríziséből áll össze. Arturo Escobar: Latin America at a Crossroads: Alternative Modernizations, Post-Liberalism, or Post-Development? Cultural Studies, 24. (2010), 1. 1-65. 7.

15 Borbás Barna: „Trón és oltár”: míg a keresztény szabadságon rágódunk, kiürülnek a templomaink. Válasz Online, 2019. október 24. Elérhető: www.valaszonline.hu/2019/10/24/politikai-keresztenyseg-keresztenydemokracia-vita/ (A letöltés dátuma: 2020. 09. 28.)

16 Uo.

17 Schanda Balázs: Magyarország keresztény kultúrájáról. Pázmány Law Working Papers, 2018/8. $1-4.1$. 
Az Alaptörvény hetedik módosítása ebben a tekintetben hoz változást, a keresztény kultúra (de továbbra sem a keresztény hit vagy vallás) védelmének kötelezettségével."18 Később úgy pontosítja álláspontját, hogy kifejti: Magyarország keresztény kultúrájának védelme nem egy keresztény kultúra létrehozatalának parancsát jelenti, hanem inkább a meglévő, adott - keresztény gyökerű - kultúra védelmének kötelezettségét, különös tekintettel arra a tényre is, hogy feltételezése szerint a keresztény kultúra ezen tág fogalma alá sorolandó számos olyan intézmény is, amellyel kapcsolatban jól látható, hogy „a keresztény eszmény és a társadalmi gyakorlat között szakadék tátong”. ${ }^{19}$

Ezen - a hivatalosság rangjára emelt, újkonzervatív ideológiát megalapozó - politika legfőbb eszköze a keresztény erkölcs alapjainak erősítése közvetetten az oktatásban, illetve közvetlenül is egyes bevett egyházak kiemelt támogatásával. Kritikusaik szerint a keresztény értékek és a keresztény szabadság hirdetésére csupán lózungként kerül sor a kormányzati szereplők részéről - a keresztény szabadság bibliai korlátainak hirdetése és azoknak a közmorál, politikai morál részévé tétele nélkül, végső soron a „következmények nélküli társadalom” felszámolása nélkül. ${ }^{20}$ Azonban - megközelítéstől, politikai szimpátiától függetlenül - tény, hogy ennek a politikai építkezésnek hangsúlyos eleme egy tudatos múltépités, amelynek része Magyarország Alaptörvényének megalkotása és folyamatos módosítása is. ${ }^{21}$

\subsection{Szociálpszichológiai, valláslélektani és egyéb vallástudományi megközelitések}

A keresztény szabadság fogalmának feltárása körében a szociológiai, a szociálpszichológiai és a kifejezetten valláslélektani megközelítések alkotnak egy további, önálló csoportot azzal, hogy ezek eredményei gyakran a teológiáról levált vallástudomány eredményeiként jelennek meg. Ezek közös sajátja, hogy a kereszténység és a keresztény szabadság fogalmát elsősorban a hiátusok és defektusok, az egészségestől való eltérések feltérképezésével kívánják megvalósítani - negatív fogalmak alkotásával kerülve közelebb a vizsgálat tárgyához, tárgyaihoz... Olyan témák, mint a konformizmus, a deviancia, a szélsőségesség jelennek meg vizsgálati tárgyakként ebben a szakirodalomban.

A leggyakrabban előkerülő vallási szélsőségek kérdésköre a hazai - és nemzetközi szakirodalomban is leginkább a vallási fanatizmus, ${ }^{22}$ a terrorizmus különféle formái, ${ }^{23}$

18 Uo. 2.

19 Schanda i. m. (17. lj.) 3.

20 Rixer Ádám: A civil társadalom helyzete Magyarországon, különös tekintettel a populizmus térnyerésére. Glossa Iuridica, 6. (2019), 3-4. 43-72. 67.

21 Rixer Ádám: A történeti alkotmány vívmányai: Utazás a múltba vagy út a jövőbe? In Balogh Judit et alii (szerk.): 65. Studia in honorem István Stipta. Budapest, KGRE ÂJK, 2017. 365-375. 366.

22 Sam Cherribi: Bad Faith: The Danger of Religious Extremism by Neil J. Kressel. Review. Political Psychology, 30. (2009), 2. 319-323.; Laurence R. Iannaccone: Religious Extremism: Origins and Consequences. Contemporary Jewry, 20. (1999), 1. 8-29.

23 Julia V. Tuskhova: ISIS and Al-Qaeda as the Determinants of Religious Extremism in the UK. Society: Politics, Economics, Law, 14. (2017), 8. 1-4. 
illetve a „hagyományos” szektakérdés különféle olvasatai formájában van jelen. Kevés azonban az olyan munka, amely a szélsőségesség (extremizmus) definícióján, illetve főbb gyakorlati megvalósulási formáin túl kifinomult szempontrendszert és az utóbbi nyomán taxatív tipológiát kínálna. Korábbi tanulmányunkban ${ }^{24}$ bemutattuk, hogy a vallási szélsőség fogalma tekintetében lehetséges egy negatív és egy pozitív meghatározás is: a negatív definíció azt mutatja meg, hogy melyek azok a jelenségek, amelyek bár a vallással, sőt intézményes vallással is érintkezhetnek, összekapcsolód(hat)nak, de mégsem tekinthetők vallási eredetű vagy vallási természetű „szélsőségnek”; a pozitív definíció pedig egy taxatív lista keretében tesz kísérletet a szélsőségek lehetséges, főbb típusainak felsorolására.

A vallási szélsőség negatív definíciója körébe kell sorolnunk például azokat a jogsértéseket, amelyek nem az adott vallás tanításaiból következnek, hanem - adott esetben - a nyilvántartásba vételi eljárás során egy csatolni elmulasztott melléklet formájában megjelenő emberi mulasztást feltételeznek. Ugyanígy nem minősülhet vallási szélsőségnek például egy vallási rendezvényen bekövetkező lopás, amennyiben ez általában nem tekinthető az adott közösség „lényegéből” következő, általánosítható jelenségnek. Szintén problematikus az, amikor egy adott (keresztény) gyülekezet vagy egy több helyi gyülekezetből álló nagyobb vallási közösség vezetőinek kisebb-nagyobb gyengeségeiből következtetünk a működés vagy tanítás általánosan szélsőséges voltára, azaz önmagában egy „rossz”, „bűnös” vezető vagy hibás vezetési gyakorlat sem eredményezhet önmagában „vallási szélsőséget”.

E körben hangsúlyoznunk kell azt is, hogy önmagában az a tény, hogy egy vallási alapú, a társadalom által tudomásul vett, de a többség által nem követett szűk csoportnorma logikailag összekapcsolható konkrét jogsértésekkel (például a cölibátus intézménye a cölibátusban élő személyek által gyermekek sérelmére elkövetett szexuális büncselekményekkel) nem feltétlenül eredményezi azt, hogy magát a vallási közösséget is „szélsőségesnek” tekintjük, különösen, ha - amint azt a felhozott példa is mutatja - a csoportnorma nem a vallási nézetrendszer „lényegéhez” tartozó elem, illetve az adott vallási közösség is érdemben fellép az adott intézmény káros implikációival, illetve a konkrét bántalmazó jelenséggel szemben. ${ }^{25}$

24 Rixer Ádám: A vallási szélsőségek tipológiája Magyarországon. Vallástudományi Szemle, 14. (2018), 4. $15-30$.

25 A Katolikus (Világ)Egyházban több hullámban zajlott, zajlik a szembesülés, illetve szembenézés ezzel a jelenséggel is. 2012. február 6. és 9. között nemzetközi tanácskozást tartottak Rómában a világ különböző egyházmegyéiből érkezett püspökök és szerzetesrendi elöljárók részvételével az Egyház hivatalos képviselői által elkövetett szexuális gyermekbántalmazások elleni fellépésről és az áldozatok megsegítéséről. Erre nézve l. Stephen J. Rosetti: Bátor szembenézés: Hatékony fellépés a gyermekek szexuális kihasználóival szemben. Korunk, 23. (2012), 4. 99-106. Az egyes országok (tagegyházainak) gyakorlatára nézve l. továbbá Jo R. Formicola: Recalibrating U.S. Catholic Church-State Relations: The effects of clerical sexual abuse. Journal of Church \& State, 58. (2016), 2. 307-330.; illetve Kathleen McPhillips: The Church, The Commission and the Truth: Inside the NSW Special Inquiry into Child Sexual Abuse. Journal for the Academic Study of Religion, 29. (2016), 1. 30-51. Ezen írások kiindulópontja - szinte minden esetben - az, hogy az ügyek eltussolásában az egyházi elöljárók mellett évtizedekig az állami hatóságok is érdemben közreműködtek. 
A pozitív definíció tekintetében - a fentiekből is következően - érdemes rögzítenünk, hogy szélsőségesnek leginkább a kiterjedt, általánositható gyakorlatokat, jelenségeket tekinthetjük; az elszigetelt, sporadikus, egy-egy személyhez köthető, az adott vallás (valláson belüli vallási irányzat) tanításaiból le nem vezethető gyakorlatokat általában nem érdemes ebbe a körbe sorolnunk. A szélsőséges jelenségek csoportosítását megkönnyítő szempont lehet:

- a szélsőség révén sérülő, a többségi társadalom által elfogadott, vallott norma típusa (hogy tudniillik jogi vagy egyéb társadalmi normatípus sérelméről van-e szó);

- hogy az adott vallási közegen, közösségen kívülre hat-e „szélsőséges” magatartás, vagy éppenséggel - döntöen - azon belül maradva fejti ki káros hatását, illetve

- hogy az - büntetőjogi értelemben - erőszakos jellegü-e.

Szűkebb témánk szempontjából is lényegesek ezek az ismérvek, amennyiben a legtágabban felfogott keresztény szabadság korlátaiként és veszélyeztetőiként is hasznos kiindulópontot jelenthetnek.

A másik fogalom, amely szintén gyakran bukkan fel e diskurzusban, a deviancia. Ez különösen azokban az esetekben válik gyakorlati és egyúttal tudományos témává, amikor egy vallási közösség (keresztény közösség) szembekerül vallási környezetével, illetve tágabb társadalmi környezetével, s „deviánssá” válik. A különböző vallások születése, illetve új keresztény közösségek létrejötte is sok esetben ilyen krízishelyzetekhez kötődik. Így jött létre a reformáció, s így születnek az újabb keresztyén egyházak azóta is. Ezért is állapíthatta meg Wolfgang Lipp, hogy a konformizmus problémája vallástörténeti probléma, ebből önállósult a szociológiának s a szociálpszichológiának köszönhetően. ${ }^{26}$

Pressing Lajos összefoglalásában háromféleképpen oldható fel a fentebb vázolt feszültség. Egyfelől a vallás beilleszkedik a társadalom intézményi és értékrendjébe, $\mathrm{s}$ az ellentmondásokat kognitív elhárítással, főként ideológiaképzéssel és racionalizálással oldja fel. Másrészt választhatja azt is az adott vallás, hogy valamilyen társadalmilag intézményesült formában úgy teremti meg az egyéni lehetőségeket, hogy részlegesen elszigetelődik a társadalom többi részétől, így csökkentve minimálisra annak „káros” hatását. Végül - harmadik lehetőségként - törekedhet a vallás arra is, hogy az egész társadalmat átalakítsa oly módon, hogy a társadalmi intézmények a vallási értékek és normák szerinti életmódot segítsék elő. Ez utóbbira példa az iszlám fundamentalizmus, míg a keresztyén egyházak rendszerint az első két út valamelyikét járják. ${ }^{27}$

A deviancia mellett a legtágabban felfogott vallástudomány használja a fennálló uralkodó rendszerhez való elvtelen alkalmazkodást jelentő konformizmus fogalmát is,

26 Tajti Enikő: Otthon a világban. A konformizmus és non-konformizmus teológiai értelmezése Róma 12:1-2 és János 4. rész értelmében. Szakdolgozat. Budapest, Baptista Teológiai Akadémia, 2018. 37.

27 Pressing Lajos: A deviancia és a vallás kapcsolata. In Münnich Iván - Moksony Ferenc (szerk.): Devianciák Magyarországon. Budapest, Közélet, 1994. 201-222. Idézi: Tajti i. m. (26. lj.) 37. 
sőt e két fogalom együtt is megjelenik - amikor a konformizmus ellenében valamifajta „innovatív deviancia” érvényesül, amikor is a vallási szabályra ráépül egy helytelen gyakorlat, gyakorlati értelmezés, és éppen a deviánsnak tekinthető magatartás állítja helyre (kísérli meg helyreállítani) a szabály eredeti jelentését. ${ }^{28}$

\section{A keresztény szabadság jogi fogalma}

E fejezetben kísérletet teszünk arra, hogy egyfelől a keresztény szabadság jogi fogalmát, klasszikus, ma divatozó jogpozitivista alapokon határozzuk meg, másfelől egy jogszociológiai megközelítésű alternatív fogalom bevezetésének lehetőségét is felvetjük az előbbi fogalom elégtelensége mellett érvelve.

A „hagyományos” megközelítés - nem csupán a keresztény szabadság sajátos jelenségének megragadása, hanem minden más kérdés esetében is - az, amely a normaszöveg elemzésével, illetve a belső bírói, alkotmánybírósági szervek, illetve nemzetközi fórumok döntéseinek „letapogatásával” előállított kontúrok segítségével rajzolja meg az adott időszak nemzetközi, adott államcsoporton (például az Európai Unión vagy Dél-Amerikán) vagy egy adott országon belül érvényesülő gyakorlatait. Ennek szakmai, illetve tudományos eszközei a főbb kortárs témák és neuralgikus, értelmezésre szoruló rendelkezések felsorolásai és elemzései, valamint azokhoz kapcsolódóan az egyedi döntésekből összeálló pillanatnyi fogalmi és értelmezési háló ismertetése, annak megjelölésével, hogy ez a háló hol kezdett el felfesleni, melyek a kényes, bizonytalan, „veszélyes” pontok. Egy ezek által nyerhető pontos képhez gyakorlatilag elegendő az állami és nemzetközi szervek döntéseit alaposan tanulmányoznunk, amenynyiben a szabadság jogi terjedelmére vonatkozó prognózisokat szeretnénk elóállítani.

$\mathrm{Ez}$ az a pont, ahol magyarázattal is kell szolgálnunk arra nézve, hogy miért is nem elegendő mindez akkor, amikor a keresztény szabadság jogi fogalmának speciális magyarországi jelentéstartományait, tartalmát keressük. Amint azt néhány példával is alátámasztjuk a későbbiekben, van egy olyan összefüggés a vizsgált területen, hogy ha jognak a ténylegesen követett, ilyenként használt szabályokat tekintjük, akkor rácsodálkozhatunk arra is, hogy - adott esetben - a jogszabályok egy része nem érvényesül, de mert ez - legalább részben - az érintettek (esetünkben a vallási entitások) számára is előnyös, ennek implikációi a hatósági döntésekben vagy akárcsak a nyilvánosság különböző színterein nem fognak megjelenni. Ha pedig nincs jogalkalmazás, nincs „jogeset” sem, s bárki számára úgy tủnhet, hogy nincs probléma sem - miközben a jog nem az előzetesen meghatározott, tételezett módon érvényesül.

Azt fogjuk tehát elnagyoltan bemutatni, hogy melyek azok az elemek, hazai gyakorlatok stb., amelyek részben bővítik (bővíthetik), részben pedig szükítik (szủkíthetik) a keresztény szabadság magyarországi fogalmát - remélve, hogy a felkínált modell képes lesz a tényleges állapotokat jobban visszatükrözni.

28 Tajti i. m. (26. lj.) 37. 


\subsection{A hagyományos fogalom}

\subsection{1. Általános elökérdések}

Hagyományos, jogias megközelítésben szabad vagyok mindarra, amit a hatályos jog kifejezetten lehetővé tesz, védelemben részesít, illetve számos vonatkozásban arra is, amit kifejezetten nem tilt meg. Amikor a keresztény szabadság jogi fogalmát kívánjuk megragadni, figyelembe kell vennünk azt a tényt is, hogy az állam által alkotott jog néhány vonatkozásban már elébe megy egyes vallási meggyőződéseknek, illetve sajátosságoknak, akár úgy, hogy azokra tekintettel lehetővé teszi a főszabálytól való eltérést (például egyes államokban fegyver nélküli katonai szolgálat engedélyezésével), akár úgy, hogy tilalmakat fogalmaz meg (például egyes államokban a vallással szoros kapcsolatot mutató öltözködési szokások, ruhadarabok viselésének vagy kifejezetten vallási jelképek elhelyezésének tiltásával). A szabályok a vizsgált terület legtöbb vonatkozásában - leszámítva néhány tilalmat - csupán a jogalkotó által felajánlott lehetőségek, amelyekkel nem kell feltétlenül élni, s az utóbbi (az elhatárolódás „negatív” szabadsága) is védelemben részesül. Fontos kiindulópont továbbá, hogy jogállami keretek között az állam nem is kíván minden lehetséges aspektust szabályozni, illetve jogalkalmazással „uralni” - általában nem is kell például jogi forma (nyilvántartásba vétel) a vallási közösség működéséhez, az csupán néhány, az elemi vallásgyakorláson túlmutató tevékenységnek, illetve bizonyos kedvezmények, juttatások igénybevételének előfeltétele. Szintén figyelembe veendő, hogy a semleges állam szerepe a vallásszabadság biztosítása körében - a lelkiismereti és vallásszabadságot közvetlenül szabályozó rendelkezéseken túl - magában foglalja egy olyan társadalmi-kulturális közeg létrejöttének elősegítését (is), amely más módokon is „kellö toleranciával segíti a szabad választást és a vallás gyakorlása számára megfelelő teret biztosít". ${ }^{29}$

Lényeges továbbá, hogy ma már a szabadság tartalmának érzékeléséhez nem elegendő egy-egy állam belső bírói fórumai által hozott döntések elemzése, tekintetbe kell vennünk a nemzetközi fórumok esetjogát is. A vallásszabadsággal összefüggő és jogi eljárássá transzformálódó konfliktusok szűkebb tárgyai között az európai fórumok elött az elmúlt időszakban leginkább a vallási jelképek viselése, nyilvános helyeken történő kifüggesztése, továbbá az adott vallással szorosan összekapcsolódó öltözködési szokások (hidzsáb, burka stb.), az oktatás egyes szexualitással, illetve etikai kérdésekkel összefüggő elemei, az egyházi fenntartású munkáltató által hozott egyes döntések, valamint a vallási meggyőződésből fakadóan visszautasított tevőleges magatartások jelentek meg.

Az ezekkel kapcsolatos bírói gyakorlatok természetszerủen változnak is, és a tudomány egyik feladata éppen annak bemutatása, hogy milyen finom vagy éppen jelentős elmozdulások következtek be az adott fórumok gyakorlatában. Ilyennek tekinthetjük például annak detektálását, hogy miközben az Emberi Jogok Európai Bírósága (EJEB)

29 Schanda Balázs: Állami egyházjog. Vallásszabadság és vallási közösségek a mai magyar jogban. Budapest, Szent István Társulat, 2012. 28. 
esetében a hangsúly egyre inkább a vallási közösségek és a munkáltatók jogainak védelmére kerül, az Európai Unió Bírósága (EUB) leginkább 2017 óta formálódó gyakorlata ${ }^{30}$ az egyéni jogok bírói úton történő érvényesítését helyezi előtérbe. ${ }^{31} \mathrm{Ez}$ különösen annak fényében izgalmas jelenség, hogy egyébként az EUB nemcsak figyelemmel van az EJEB döntéseire, hanem általában követi is annak gyakorlatát (annak ellenére is, hogy nem alkalmazza közvetlenül az Emberi jogok európai egyezményét). ${ }^{32}$

A terület jogalkalmazói gyakorlata azonban nem csupán a hagyományos problémák újszerű jogi megközelítésére ad példákat, amennyiben új és gyorsan növekvő jelentőségủ kérdések is megjelennek az európai térségben. Ez utóbbi körbe sorolhatók például a „sharíatanácsok, amelyek családjogi és személyállapoti ügyekben, választottbíróságok módjára alkalmaznak sharíat. A [...] valódi kérdés tehát az: megteheti-e egy európai állam, hogy nemcsak hagyja, hanem támogatja is a sharía érvényesülését olyan ügyekben, amelyekben az állami jog nemcsak rendelkezésre áll, hanem valószínúleg más szabályok szerint rendezné egy jogvita kimenetelét."33 Az ezen ügyekben születő döntések felvillantják a keresztény szabadság kontúrjait is, pontosabban annak mibenlétére, korlátaira, mértékére vonatkozó jogi prognózisokként funkcionálva vannak mindazok segítségére, akik számára ezek a kérdések lényegesek.

Ezek azok a főbb kiindulópontok, amelyek tanulmányozása révén hagyományosan kialakíthatunk egy prognózist arra nézve, hogy mi az, ami az adott konkrét államban védelemben részesülhet, azaz - témánk szemszögéből - melyek lesznek a keresztény szabadság jogokkal definiálható elemei, és hol húzódnak e jogok hozzávetőleges határai. A normatív és egyedi jogforrások (jogszabályok és hatósági döntések) által megalapozott prognózis azonban számos vonatkozásban nem lesz képes igazán pontos képet, szükséges mélységủ elemzést adni arról, hogy mi a szabadság tényleges, praktikus terjedelme. S ez az, ami miatt - Magyarország példáját használva - kísérletet teszünk egy hasznosabb, reflexívebb megközelítés alkalmazására.

\subsubsection{A magyarországi helyzet}

E helyütt nem tartjuk feladatunknak a lelkiismereti és a vallásszabadság magyarországi helyzetének elemzését, az elmúlt évtizedek jogfejlődésének részletes bemutatását. Azokra a jogalkotási csomópontokra és különösen jogalkalmazási gyakorlatokra összpontosítunk, amelyek rendkívüli hatást gyakoroltak és gyakorolnak ma is arra a jelenségcsoportra, amelyet a keresztény szabadság jogi kereteiként határoztunk meg. E körben természetesen kiemelten kezeljük azokat a tényeket, amelyek már egyértelműen egy kiigazítás igényét, egyenesen szükségességét is felvetik: azokat, ame-

30 A kifejezetten vallási alapú konfliktusok döntő többségében az EUB Nagytanácsa a 2000/78/EK irányelvének vallási megkülönböztetésre vonatkozó tilalmát, illetve egyházi (vallási) szellemiségü munkáltatókra vonatkozó kivételeit alkalmazta.

31 Uitz Renáta: Lelkiismereti és vallásszabadság a multikulturális Európában. Hogyan tovább? Hova tovább? Jogtudományi Közlöny, 74. (2019), 5. 213-228. 223.

32 Uo. 222.

33 Uo. 216. 
lyek a 3.1.1. alpontban körülírt prognózis eredményéhez képest komoly elmozdulásokat eredményeznek a keresztény szabadság eme dinamikus, új fogalmában.

A szférát szabályozó korábbi törvény, a lelkiismereti és vallásszabadságról, valamint az egyházakról szóló 1990. évi IV. törvény (Lvt.) 9. \$ (1) bekezdése és 12 . $\mathbb{S}$ (1) bekezdése alapján az egyház nyilvántartásba vételéről a székhelye szerint illetékes megyei bíróság, illetőleg a Fővárosi Bíróság határozott, nemperes eljárásban. A 2012 előtti bő húsz évben az egyházak nyilvántartásba vételi eljárása teljesen formális volt (pedig kizárt, hogy a jogalkotó eredeti szándéka ez lett volna) leginkább azért, mert a bíróságok a kérelmezők nyilatkozatainak megtörténtén, illetve az általuk kötelezően benyújtandó dokumentumok létén túl nem végeztek érdemi vizsgálatokat: sem a dokumentumok tartalmának - azaz tényállításainak - valódisága, sem pedig a szervezetek létrejöttének tényleges okai és céljai tekintetében. Azaz, amenynyiben a megfelelő alakszerűséggel benyújtott dokumentumok alapján felsejlett egy törvényes és legalább elemi vallási tartalmakat is rögzítő cél, úgy a nyilvántartásba vétel - az esetek döntő többségében - automatikusan megtörtént. Az egyházi jogállás elnyerése 1990 után - az akkor is létező egyesületi formával szemben - komoly adózással összefüggő és egyéb többletjogosultságokat jelentett. Tekintve, hogy abban az időszakban az egyesületekre általánosan irányadó tíz fővel szemben száz fővel már alapítható volt egyház - nyilvánvaló, hogy miért választotta szinte minden vallási közösség az egyházi jogállást. Tény, hogy a rendszerváltozás idején tudatosan rendkívül könnyűvé tett szervezetalapítás lehetősége megnyitotta a kaput a visszaélések és a vallási tevékenységet csupán álcaként használó tevékenységek előtt is.

A vallási közösségekkel kapcsolatos jogalkotás leggyakrabban akkor kerül reflektorfénybe, amikor egyes szélsőséges(nek látszó) vallási gyakorlatokra reagálva az erre jogosult elszánja magát a változtatásra. ${ }^{34}$ Magyarországon a rendszerváltozást követően több hullámban is felmerültek problémák, visszaéléses gyakorlatok, így például - még 2010 elött - a kegytárgyakkal kapcsolatos mentességek nyomán, ${ }^{35}$

34 Krystyna Daniel - W. Cole Durham: A vallási azonosságtudat mint a nemzeti identitás összetevője. Fundamentum, 1. (1997), 2. 5-21. 6.

35 A hitélethez szükséges kiadvány, kegytárgy előállítása, értékesítése nem minősül gazdasági-vállalkozási tevékenységnek, aminek a jelentősége abban áll, hogy az adott egyház ezáltal ezen tevékenység vonatkozásában mentesül adó- és járulékfizetési kötelezettségei alól. Korábban néhány alkalommal történt kísérlet arra, hogy nem vallási természetủ tárgyakat új egyház alapításával kegytárgyként forgalmazzanak, így pl. figyelmet érdemel a Győrújbaráti Motoros Egyesület kísérlete, amely egy motoros cikkeket árusító bolt köré szervezett volna egyházat abból a célból, hogy a boltban kapható tárgyak mindegyike kegytárgynak minősülhessen, s így komoly anyagi előny realizálódhatna / realizálódhatott volna. A kegytárgyként (vámmentesen) behozott árukat aztán - szintén kegytárgyként - adómentesen értékesítették volna. Honlapjukon sokáig olvasható volt: „egyesületünk tagjai minden évben hálát adnak a Szent Karburátor Istenének és gyermekének a Szent Injektornak." Rixer Ádám: A vallás fogalmáról. Jogelméleti Szemle, 12. (2011), 4. 1-8. 5. Itt jegyezzük meg, hogy nem tartozik a keresztény szabadság körébe a jog kikerülésének szándékával - valamilyen haszon stb. reményében - elkövetett jogsértés. A keresztény szabadság fogalma e dolgozatban értéktartalommal bír, nem foglalja magában a szándékoltan visszaélésszerủ egyéni, közösségi vagy társadalmi szintű, akár kifejezetten állami gyakorlatok teremtette „lehetőségeket” - ennyiben igazodik is a fogalom teológiai jelentéséhez, tartalmához. 
a külföldről érkező egyházi szolgálattevőkre irányadó enyhébb letelepedési szabályokkal, illetve könnyített vízumügyintézéssel összefüggésben, a „perselypénz” adómentességével kapcsolatban és a sorkatonai szolgálat kikerülését célzó egyházalapításokkal összefüggésben is - egyebek mellett. Ám ezekkel a jelenségekkel kapcsolatban is elmondható, hogy a hatóságok nem vagy csak a legkirívóbb esetekben léptek fel, így például az elhíresült Gyurcsok József-féle ügyben, ${ }^{36}$ amelyben az ügyészség vállalta a nyílt fellépést is. A legtöbb esetben inkább a jogszabályok (majdnem minden esetben törvények) megváltoztatására került sor, az egyébként rendelkezésre álló jogalkalmazói eszközök bevetése helyett.

Az első átfogó - és egyúttal az érdemi szigorítás irányába elmozduló - szabályozási kísérlet a lelkiismereti és vallásszabadság jogáról, valamint az egyházak, vallásfelekezetek és vallási közösségek jogállásáról szóló 2011. évi C. törvény volt, amelyet azonban az Alkotmánybíróság közjogi érvénytelenség miatt alkotmányellenesnek nyilvánított, és ezért megsemmisitett. ${ }^{37} \mathrm{Az}$ Alkotmánybíróság döntését ${ }^{38}$ - egyebek mellett - arra alapozta, hogy a törvény az országgyülési elismerés tekintetében az Országgyűlésre vonatkozó eljárási határidőket és kifejezett döntéshozatali kötelezettséget, valamint a kérelmező szervezetek oldalán a fellebbezés lehetőségét is nélkülözte. Ehhez tegyük hozzá, hogy a jogszabály rendkívül előkészítetlen volt, semmilyen előzetes hatásvizsgálat nem készült hozzá. ${ }^{39}$ Lényeges, hogy az állam itt is a korábbi logikát követte: egy probléma (kiegészítő egyházi normatívára vadászó álegyházak létrejötte) felmerülésekor nem az adekvát megoldást választotta, azaz nem a jogalkalmazó jog által lehetővé, sőt kötelezővé tett fellépésére (bírósági nyilvántartásba vételi eljárások érdemivé tételére, illetve ügyészi fellépések sorozatára), hanem - vélhetően politikai okokból - a teljes szféra életébe radikális beavatkozást jelentő törvényalkotásra került sor.

36 A nevezett személy által folytatott távgyógyítás nem szerepelt az egyház (Egyetemes Szeretet Egyháza) alapító okiratában - ez volt a Pest Megyei Bíróság előtti eljárás tárgya.

37 A törvény megszületésének látszólagos, a médiumokban kommunikált kiváltó oka az a 2000-es évek végétől elharapódzó gyakorlat volt, amelynek keretében magánfenntartású idősek otthonai - döntően az általuk gondozottak bevonásával, de tényleges vallási tevékenység folytatása nélkül egyházzá alakultak, ily módon szert téve az ún. egyházi kiegészítő normatívára is.

38 A döntés részleteit l. a 164/2011. (XII. 20.) AB határozatban.

39 A 2011. évi C. és 2011. évi CCVI. törvények végső - elfogadott - szövegváltozataihoz igazodó érdemi hatástanulmányok (előzetes hatásvizsgálatok) azért is lényegesek lettek volna, mert igazolhatták volna a már másfél évtizeddel korábbi országgyủlési vitákban is nagy teret kapó félelmeket, amelyek a destruktív - gyermekeket elnyelő, családokat szétzúzó, elesett emberek vagyonát megkaparintó és tagjaikat csoportos öngyilkosságra, valamint rituális emberáldozatra biztató - szekták térnyerésétől kívánták volna megóvni a magyar társadalmat. Félő, hogy az előzetes - érdemi - hatásvizsgálatok elmaradásának egyik döntő oka éppen az a tény lehet, hogy az említett félelmek nem bizonyultak valósnak. Sőt egy valóban objektív felmérés vélhetően azt támasztaná alá, hogy a 2012-ben kényszerűségből vallási egyesületté átalakult kisegyházak döntő többségének ma Magyarországon jelentős hatása van például a társadalmi kohézió és szolidaritásra késztetettség erősítésében, a társadalom szövetének - kevéssé látványos, ám valós mértékű - megújításában. Rixer Ádám: A hatásvizsgálatok jelentősége és egyes szempontjai a vallási szervezetek szabályozása körében. Kodifikáció, 2. (2013), 1. 91-102. 95. 
Az ezt követően, hasonló elnevezés alatt elfogadott 2011. évi CCVI. törvény (Ehtv.) több eljárási jellegű problémát kiküszöbölt, ám néhány - komoly vitákat eredményező - tartalmi probléma megmaradt, elsősorban az Országgyülés általi elismerés fenntartásával, tekintve, hogy bár az Ehtv. 14. \$-a kilenc taxatív elismerési szempontot is meghatározott, s ezek közül az első hat tekintetében a miniszter határozata (többékevésbé) kötötte is az Országgyűlést, ám az utolsó három megléte („bizonyítottsága") tekintetében az Országgyủlés tejesen szabadon mérlegelhetett. A teljesen szabad mérlegelést érdemben nem befolyásolta, hogy elutasító döntését az Országgyűlésnek határozatában indokolnia is kellett. Ugyanígy nem jelentette tartalmi kontroll megvalósulását, hogy bár az egyházi elismerést kérő, vallási tevékenységet végző szervezet az Alkotmánybíróságtól kérhette az országgyülési határozat felülvizsgálatát, az Alkotmánybíróság csupán az Országgyủlés egyházként történő elismerésre irányuló eljárásának törvényességét vizsgálta (volna) felül: azt nem, hogy - adott esetben - „a közösségi célok érdekében történő együttmüködés iránti szándékát és annak hosszú távú fenntartására való képességét" az adott szervezet valóban bizonyítani tudta-e. ${ }^{40}$

Nem kitérve az elmúlt tíz év valamennyi jogalkotási fejleményére, az mindenképpen jól látható, hogy a 2010 után a nagyobb, történelmi, illetve „bevett” egyházak „helyzetbe hozására” irányuló jogalkotási törekvéseket az $\mathrm{AB}$ tevékenysége több ízben is korrigálta: ${ }^{41}$ kiemelhető például a 7/2017. (VII. 18.) AB határozat a személyi jövedelemadó meghatározott részének az adózó rendelkezése szerinti felhasználásáról szóló 1996. évi CXXVI. törvénnyel (Szf. tv.) kapcsolatos mulasztásban megnyilvánuló alaptörvény-ellenesség megállapításáról és alkotmányjogi panasz elutasításáról. Más AB határozatok mellett a 23/2015. (VII. 7.) AB határozat is érdemi törvénymódosítást eredményezett: az elmúlt 7-8 évben folyamatos és intenzív küzdelem alakult ki a vallási szférát újraszabályozni kívánó jogalkotó, a vallási entitások egy része és az Alkotmánybíróság között. A küzdelemnek néhány esetben a nemzetközi fórumok is részeseivé váltak, ${ }^{42}$ és a vizsgált témával összefüggő alaptörvény-módosításra is volt példa ebben az időszakban.

40 Ehtv. 14. \$i) pont.

41 L. részletesebben Köbel Szilvia: Az Alkotmánybíróság vallásszabadsággal és vallási közösségekkel kapcsolatos gyakorlata. In Köbel Szilvia (szerk.): Az állami és a felekezeti egyházjog alapjai. Budapest, Patrocinium, 2016. 207-234.

42 Legismertebb példaként az Emberi Jogok Európai Bíróságának (EJEB) héttagú kamarája 2014. április 8-án $5: 2$ arányban elmarasztaló ítéletet hozott Magyarországra nézve 17, egyházi státuszát a lelkiismereti és vallásszabadság jogáról, valamint az egyházak, vallásfelekezetek és vallási közösségek jogállásáról szóló 2011. évi CCVI. törvény alapján (Ehtv.), 2012. január 1-jén, illetve 2012. március 1-jén elveszítő vallási felekezet egyesített panaszai tárgyában. A Bíróság arra a következtetésre jutott, hogy a magyar állam a kérelmezők vonatkozásában megsértette az Emberi jogok európai egyezményében biztosított egyesülési jogot (11. cikk) a vallásszabadsághoz való joggal (9. cikk) öszszefüggésben, tekintve, hogy a jogszabály csak a mellékletében felsorolt „bevett egyházak” egyházi státuszát ismerte el, a többi, korábban egyházi státusszal rendelkező szervezet pedig egyesületi minősítést kapott, miközben az egyházzá minősítést az Országgyűlés egyúttal a bíróságok hatásköréből saját hatáskörébe vonta. Az EJEB az eset és az érvek vizsgálata során kifejtette: a vallásés lelkiismereti szabadság biztosításához hozzátartozik, hogy az állam független marad, és pártatlan 
A rendes bíróságok jogalkalmazó gyakorlata is, amint azt látni fogjuk, a jogi korlátokat feszegetően megengedő - éppen ez az egyik oka annak, hogy egy alternatív fogalommeghatározás (jelenségleírás) szükségessége merül fel...

\subsection{Az újabb, javasolt fogalom és annak egyes elemei}

Itt egy - a téma szempontjából aktualizált, konceptualizált - jogfogalom kerül a középpontba, amely alkalmas lehet arra is, hogy egy árnyaltabb fogalommal pontosítsa, mélyítse vagy éppen módosítsa azt a képet, amely a keresztény szabadság fogalmának jogszabályhelyeken és bírói döntéseken alapuló vizsgálata révén nyerhető. Kiindulópontunk - ahogyan azt korábban is jeleztük - az, hogy vannak olyan szempontok, amelyek elvesznek a jogpozitivista megközelítés nyomán nyerhető szabadságfogalom terjedelméből, és vannak, amelyek hozzátesznek, tágítva, bővítve azt. Egy tágabb jogfogalomba ugyanis beletartozhat a jogrontó jogszokás, a jogrontó szokásjog is, a jogalkalmazó szervek azon - jogellenes - magatartása, amely soha nem kerül bírói vagy egyéb szerv elé, tekintve, hogy az érintettek (a jogalanyok) számára pozitív eredménnyel jár. Ez egy jogszociológiai megközelítés, amely teljesebb képet rajzol az egyes keresztény szabadsággal is összekapcsolható jelenségekről, ráirányítva a reflektorfényt azokra a jogi természetü - leginkább mulasztásban megnyilvánuló - jelenségekre is, amelyek a jog betűjéből és/vagy a hatósági döntésekben megjelenő „hivatalos" jogalkalmazói gyakorlatból nem olvashatók ki.

Melyek tehát azok a területek (állami gyakorlatok), amelyek módosítják a szabadság terjedelmét, anélkül azonban, hogy ennek nyoma lenne a normatív vagy egyedi jogforrásokban?

\subsubsection{Jogalkalmazói gyakorlatok}

A korábbi példák is mutatják, hogy a vizsgált területünkön az állam gyakran tartózkodó ott is, ahol beavatkozhatna, sőt köteles lenne beavatkozni. Ez a tény önmagában

szabályozást alakít ki a vallási közösségek tekintetében. Véleménye szerint azáltal, hogy a parlament hatáskörébe vonta, mely vallási közösségeket nyilvánítja egyházzá, megsértette az Egyezmény 9. cikkét (a bíróság a Metropolitan kontra Besszarábia-ügyre hivatkozott). Az EJEB a továbbiakban a 9. cikk 2. szakasz fennállását vizsgálta, tehát azt, hogy a korlátozás törvényben meghatározott-e, illetve arra a közbiztonság, a közrend és a közegészség vagy a közerkölcs, illetve mások jogainak és szabadságainak védelme érdekében került-e sor. A bíróság megállapította a 2011. évi CCVI. törvény korlátozó voltát. Továbbá álláspontja szerint az állami pénzekkel való visszaélés megakadályozása mint közérdekủ cél megállja ugyan a helyét, ám a Bíróság arra a következtetésre jutott, hogy a korlátozás nem arányos az elérendő céllal, tekintettel arra, hogy a magyar állam intézkedése eltúlzott és felettébb szigorú. Magát a közérdeket azonban nem vonta kétségbe Strasbourg, csupán egy enyhébb, a vallási közösségekkel jobban együttmúködő és az Országgyủléstől függetlenebb szabályozást tartott indokoltnak. Utóbb, a korábban megállapított jogsértések miatt vagyoni és nem vagyoni kártérítést ítélt meg több panaszos tekintetében az EJEB 2016. június 28-án. A megítélt kártérítések 40 ezer és 140 ezer euró közötti összegűek voltak. L. Rixer Ádám: Az állam és a vallási közösségek kapcsolata a mai Magyarországon. A vallási közösségek nyilvántartása és pénzügyei a jogi szabályozás tükrében. Államtudományi Mühelytanulmányok, 2. (2017), 1. 1-45. 17. 
nem minősíti a szféra szereplőit, egyes aktorait (a vallási entitásokat), a közösségeket, illetve egyéneket, de jelzi, hogy a keresztény szabadság (és általánosságban a vallási szabadság) jogi megközelitésben szélesebb körü is lehet annál, amit a jogszabályok állami szervek általi maradéktalan betartása esetén tapasztalnánk (azaz annál, amit a jogszabályok első olvasásakor feltételezhetnénk). Miután ez tipikusan egyes szabályok megszegésével szembeni fellépések, állami beavatkozási kötelezettségek elmulasztását, „visszafogott” teljesítését jelenti, összességében ez a gyakorlat is bővíti, tágítja a keresztény szabadságot (is), azaz a keresztények által élvezett tényleges jogi lehetőségek körét (természetesen csak akkor, ha a jog betartásának hiányát lehetőségbővülésként értelmezzük, nem pedig kizárólagosan a jogrendszer, illetve a teljes jogi rendszer negatív tüneteként).

A nyilvántartásba vétel régi gyakorlata, az ügyészségek „bátortalansága” mellett további példák is felhozhatóak ebben a körben (az állami szervek elnéző magatartására): például az elmúlt évtizedekben mindvégig megfigyelhető, hogy miközben a 19. század vége óta a polgári házasságkötésnek meg kell előznie az egyházit, a hatóságok nem lépnek fel az ezzel ellentétes gyakorlattal szemben, továbbá - egy friss példát keresve - a Covid-19 koronavírus-járvány miatt elrendelt, és az egyházakat is érintő korlátozások kapcsán az állami szervek számos - piaci - entitás esetében ellenőrizték a szabályok (például távolságtartás, maszkviselés stb.) betartását, míg az egyházak esetében ettől eltekintettek. Természetesen, ha a „szabadság” terjedelme nőhet a jogalkalmazó szervek magatartása révén (akár a jogszabályok keretei között, akár azokon túlterjeszkedő gyakorlatokkal), akkor a szűkítést eredményező gyakorlatok is lehetségesek. Magyarországon azonban - amint arra a 3.1.2. alpontban már utaltunk - inkább a jogalkotás esetében figyelhető meg (trendszerúen) ennek gyakorlata.

\subsubsection{Egyházi belső jog}

A második vonatkozás, amely bővíti a keresztény szabadság állami jogforrásokból kiolvasható terjedelmét, nem más, mint az állam által elismert (lehetővé tett) egyházi belső jog. A bővülés (értsd: tágabb mozgástér lehetősége) akkor is egyértelmű, ha egyébként az egyházi belső szabályok nem írhatják felül az állami jogot, de azzal párhuzamosan, illetve az az által nem érintett területeket, kérdéseket rendezve egy érdemi, önálló szabálytömeget biztosíthatnak. ${ }^{43}$ Tehát eme jogi - ám az állam által közvetlenül nem befolyásolt - szegmens fejlettsége, rétegzettsége, önálló életképessége is nagymértékben befolyásolja a keresztény szabadságot, amennyiben a vallási nézetek, illetve előírások megfogalmazásával, egyes életviszonyokra konkretizálásával

43 Ehtv. 8. \$ (2) bekezdése értelmében: „A vallási közösség hitelvei, belső törvénye, alapszabálya, szervezeti és működési szabályzata vagy azoknak megfelelő más szabályzata (a továbbiakban együtt: belső szabály) alapján hozott határozat érvényre juttatására állami kényszer nem alkalmazható, azt állami hatóság nem vizsgálhatja. A vallási közösség belső szabályon alapuló döntését állami szerv nem módosíthatja vagy bírálhatja felül, a jogszabályban nem szabályozott belső jogviszonyokból eredő jogviták elbírálására állami szervnek nincs hatásköre." 
hozzájárul(hat)nak az adott vallás teljesebb megéléséhez vagy az egyes (közszolgáltatási vagy éppen munkavégzéssel összefüggő) jogviszonyok tartalmának pontosabb megértéséhez is. Itt kell megjegyeznünk, hogy a jogi típusú keretek „szélessége” részben abból is következik, hogy a jogalkotó a vallási entitások esetében - számos vonatkozásban - eleve lehetővé teszi a föszabálytól való eltérést (leginkább a szervezet alapítása, belső felépítése, működése körében) ${ }^{44}$ illetve egyes szervezettípusok esetében olyan pénzügyi, gazdasági természetü többletjogosultságokat biztosít, amelyek önmagukban is a lehetőségek bővülését eredményezik. ${ }^{45}$ Ennél a pontnál természetesen szó sincs jogellenességről, csupán egy párhuzamos jogi rend létéről.

A problémák jelentős része nem is a belső szabályok létével kapcsolatban, hanem a „közcélú”, a társadalom szélesebb rétegei számára hozzáférhető, szolgáltató jellegủ tevékenységekkel összefüggésben figyelembe veendő sajátos (belső, egyúttal vallási alapú) többletszabályok tartalmával, azok értelmezésével kapcsolatosan kerül elő. Például a nyugati jogrendszerekben gyakran cizellált szabályozás és esetjog védi az egyházi munkaadó - éppen az említett normák által is konkretizálódó - sajátos jellegét az alkalmazottakkal szemben, miközben az alkalmazottak magánszférájának védelme is egyre hangsúlyosabb tényezőként jelenik meg ezekben a vitákban ${ }^{46} \mathrm{~A}$ keresztény erkölcs követelményei nem tekinthetők az elvárhatóság mértékét meghaladónak, fontos azonban, hogy ezeket az adott egyház egységesen és következetesen alkalmazza, ${ }^{47}$ illetve - a másik oldalról - a lojalitás érvényesítésének is megvannak az államilag is érvényesíthető határai: egyes okszerű elvárások mellett tehát valamilyen mértékben tiszteletben kell tartani a munkavállaló magánszféráját is. ${ }^{48}$

Magyarországon is a legizgalmasabb, s jelen helyzetben leggyakoribb kérdés is, hogy hol húzódik a határ a „belügy”, az adott vallási entitás által szabadon rendezhető döntési helyzet és az állami szabályok rendezési igénye között, különösen az egyházi fenntartású intézmények belső müködése, alkalmazási és igénybevevői ${ }^{49}$ jogviszonyokkal kapcsolatos kérdések körében élő ez a probléma. ${ }^{50} \mathrm{~S}$ itt a kiindulópont nyilván annak rögzítése, hogy nincs és nem is lehet totális, jogi síkon is megvalósuló elkülönülés (autonómia): a Reynolds v. United States ügyben ${ }^{51}$ az Egyesült Államok Legfelsőbb Bírósága különbséget tett meggyőződés és cselekvés között, és arra jutott, hogy a kormányzatnak tág hatásköre van a vallásos cselekvés szabályozására:

44 Ld. pl. a 2011. évi CCVI. törvény 9/B. és 11/A. \$-ait.

45 Ld. részletesebben Ormóshegyi Zoltán - Rixer Ádám: Magyarországi vallási közösségek pénzügyi forrásai és gazdálkodása a jogi szabályozás tükrében. In Köbel i. m. (41. lj.) 176-207.

46 Schanda i. m. (29. lj.) 115.

47 Uo. 117.

48 Uo. 116.

49 Ismert és tanulságos jogesetként l. Fővárosi Ítélőtábla 2Pf.21.318/2004/3.

50 Ezekben az esetekben az államnak sem csupán a vallási közösségekből való kiválás szabadságát kell biztosítania, e vonatkozáson túli szempontokat is érvényesítenie kell.

5198 US (8 Otto) 145 (1878). Idézi Russell L. Weaver: Szólás- és vallásszabadság az Amerikai Egyesült Államokban. Budapest, Wolters Kluwer, 2019. 492. 
„A törvények a cselekedetek irányítására szolgálnak, és míg a puszta vallásos meggyőződésekbe és véleményekbe nem tudunk beleavatkozni, a cselekedetekbe igen. Kimentheti valaki az ellenkező irányú [ti. az állami szabályokkal ellentétes] cselekedeteit vallási meggyőződése okán? Ezt engedni annyit tenne, hogy a vallási meggyőződések doktrínái az ország törvényei fölött állnak, és tulajdonképpen minden egyes ember számára lehetővé teszik, hogy önmaga joga szerint éljen. A kormányzat ilyen körülmények között csak névlegesen létezne."52

További izgalmas és új szakirodalmi részkérdés a bibliai szövegek egyházi fenntartású intézmények belső dokumentumaiban való felhasználásának, azokba történő beépülésének a problematikája, amely szintén szoros kapcsolatot mutat az alkalmazási, fegyelmi stb. kérdésekkel is. ${ }^{53}$

\subsubsection{Keresztény önkorlátozás}

Vannak olyan mozzanatok is, amelyek látszólag szűkítik a keresztény szabadság jogi kontúrjait. Látszólagosan, mert a szűkítő felfogás (koncepció) nem a jogalkalmazó szervek oldalán jelenik meg, hanem a potenciális alanyok (igénybevevők) oldalán. Ezek azok az esetek, amikor - esetünkben a keresztény meggyőződés(ek) alapjain - a formális jog által ténylegesen lehetővé tett intézményes megoldásoktól egy egyén vagy egy nagyobb csoport saját, önkéntes döntésével távol tartja magát; ez a negatív szabadság, hogy tudniillik önkéntesen lemondhatok bizonyos jogok (szabadságok) gyakorlásáról, akár úgy, hogy eme jogokkal egyetértek (például házassághoz való jog), de a magam esetében a páli ajándékot érvényesítem (azaz nem kívánok házasságot kötni), akár úgy, hogy nem is értek egyet a jog által biztosított lehetőséggel, annak bárki általi igénybevételét kifejezetten vallási alapon utasítva el (például azonos nemüek házassága, ha a jog lehetővé teszi - Magyarországon jelenleg nincs erre lehetőség). Léteznek olyan viszonylatok is, amelyekben, ahogyan erre korábban már utaltunk, az állam - felismerve a vallási előírások tartható álláspontként megjelenő interpretációja és az állami előírások morális konfliktusát - alternatív szabályozást tart fenn (pl. fegyveres és fegyvertelen katonai szolgálat egyidejü lehetővé tételével). Természetesen a vallási megfontolásból eredő önkorlátozás esetében érvelhetünk úgy is, hogy az valójában nem a szabadság korlátozása, hanem éppenséggel a szabadság megvalósulása, amennyiben valaki a jog által felkínált valamely lehetöséggel szabad és felelös döntést hozva nem kíván élni. Jogi jellegü korláttá ezek annyiban válnak, amennyiben az adott közösség tagjai körében jogszokásként állandósulnak.

A fenti néhány példával azt kívántuk érzékeltetni, hogy melyek is azok a tényezők, amelyek érdemben bővítik, illetve szűkítik a keresztény szabadság terjedelmét

52 Uo.

53 Vö. Rixer Ádám: A Biblia szövegeinek felhasználhatósága az egyházi fenntartású intézmények belső dokumentumaiban. In Birher Nándor - Homicskó Árpád Olivér (szerk.): Az egyházi intézmények müködtetésének etikai alapjai. Budapest, KGRE ÁJK, 2019. 25-36. 26. 
az elmúlt évtizedek Magyarországán. Önállóan nem említettük, de izgalmas összefüggés az is, hogy a jogalkalmazó szerveknek bizony fel kellett nőniük a jogállami viszonyok logikáihoz: az első időszakban a jogalkalmazói gyakorlatok fentebb vázolt „engedékenysége” részben annak is volt köszönhetö, hogy a bírák egy része bizonytalanul kezelte az új jogintézményeket. Néhány esetben egészen mulatságos döntések születtek például azzal összefüggésben, hogy mit is jelentene az a rendelkezés, miszerint az egyházon belüli ügyek tekintetében nem vehető igénybe állami kényszer. ${ }^{54}$

\section{A keresztény szabadság teológiai fogalma}

A keresztény szabadság mint a teológia számára is lényeges kérdés a szakirodalom
tanúsága szerint néhány gondolati csomópontban sủrüsödik: minden ezt tárgyaló
munka kitér az ember legáltalánosabb döntési szabadságára, ${ }^{55}$ Isten fiainak szabad-

54 Az egyik ügyben az a kérdés került a középpontba, hogy az egyház tulajdonában lévő ingatlan kiürítése iránti igény bírói úton érvényesíthető-e. A perbeli ingatlan, amelyen a helyi egyházközösség római katolikus plébánia épülete áll, a felperes tulajdona volt. Az ingatlanban az alperes lakott, akit nyugállományba vonulása miatt a papi szolgálat alól felmentettek. A felperes keresete az ingatlan kiürítésére irányult arra hivatkozással, hogy azt az alperes jogcím nélkül használja, és egy korábbi - írásos - megállapodás ellenére sem ürítette ki. Az alperes a kereset elutasítását kérte. Vitatta, hogy az ügyben a magyar állam valamely hatósága eljárhatna. Hivatkozott arra, hogy beteg, idős ember, aki kiköltözésre nem kötelezhető az egyházi törvények alapján.

Az elsőfokú ítéletben a keresetnek helyt adva kötelezte az alperest arra, hogy a perbeli ingatlant 15 napon belül ürítse ki. Ezzel szemben az alperes fellebbezése folytán a másodfokú bíróság végzésében az elsőfokú ítéletet hatályon kívül helyezte, és az eljárást megszüntette. Indokolásában a másodfokú bíróság kifejtette, hogy az alperes sajátos egyházi jogviszony alapján volt jogosult az ingatlan használatára, így a használat jogcíme nem a Ptk.-ban, illetőleg a lakások és helyiségek bérletére, valamint az elidegenítésükre vonatkozó egyes szabályokról szóló 1993. évi LXXVIII. törvényben (Lt.) szabályozott bérleti jogviszony. A plébánosi jogviszony megszűnése esetére a felek jogait és kötelezettségeit az egyházi törvények szabályozzák. A végzés ellen benyújtott felülvizsgálati kérelmében a felperes kifejtette, hogy az egyházi jogi személy tulajdonhoz való joga az alkotmány védelme alatt áll és a tulajdonosi jogosítványoknak a Ptk. szabályai és az Lt. 23. \$(2) bekezdése és 75 . $\mathbb{S}$

(1) bek. $b$ ) pontja alapján lehet érvényt szerezni.

A felülvizsgálati kérelmet a Legfelsőbb Bíróság alaposnak találta, amennyiben igaz ugyan, hogy az (akkori) Lvtv. 15. \$-ának (2) bekezdése szerint az egyház belső törvényeinek, szabályainak érvényre juttatására állami kényszer nem alkalmazható, ám ez a rendelkezés egyfelől nem zárja ki az egyház belső törvényein, szabályain túl meglévő magyar jogszabályok alkalmazását, másfelől helyes értelmezése szerint csak az egyházon belüli ügyek tekintetében nem vehető igénybe az állami kényszer, mert e körben kell érvényesülnie az egyház védett, belső autonómiájának. Az adott jogviszonynak a keresetben érvényesített része, azaz az ingatlan visszaadására irányuló tulajdonosi igény azonban nem tartozik az említett rendelkezés hatálya alá, ezért elbírálására a Ptk. és az Lt. megfelelő jogi rendelkezései az irányadók. Mindezekre tekintettel a másodfokú bíróság végzésében tévesen jutott arra a következtetésre, hogy a felperes követelése bírói úton nem érvényesíthető - mondta ki a Legfelsőbb Bíróság (Legfelsőbb Bíróság Pfv. III. 23. 115/2000. sz.).

55 Egyes bibliai szövegek szerzői olyannyira hangsúlyozzák Isten akaratának szuverén voltát (Iz 6,9k; Róm 8,28kk; 9,10-21; 11,33-36), hogy esetleg úgy tűnhet: a szövegek nem ismerik el valóságosnak az ember választási szabadságát. Valójában azonban az egész bibliai hagyomány feltételezi, hogy az ember képes a szabad elhatározásokra: az első bün elbeszélésétől kezdve (Ter 2-3; vö. 4,7) folyamatosan hivatkozik döntési képességére, ugyanakkor aláhúzza felelősségét. [...] Az ember feladata, hogy válasszon az áldás és az átok, az élet és halál között (vö. MTörv 11,26kk; 30,15-20), 
ságára, Izrael önmagán túlmutató jelentőségű megszabadítására, ${ }^{56}$ Jézus szabadító küldetésére, ${ }^{57}$ valamint e szabadság természetére ${ }^{58}$ gyakorlásának szabályaira, ${ }^{59}$ korlátaira. ${ }^{60} \mathrm{~A}$ keresztény teológia alaptétele a vizsgált vonatkozásban, hogy „[a] szabadságra Krisztus vezetett minket”. Pál apostol a galatáknak írott levelében rögzítette ezt a mondatot (Gal 5,1), a keresztény szabadság alaptételét, a krisztusi megváltásnak minden emberhez szóló örömhírét, amely túl is mutat a Jézus földi jelenléte idején általa tett csodákon és jeleken, amennyiben a bűnösöknek bűneik bocsánatát, a halálra

hogy megtérjen, és ebben kitartson egészen élete végéig (Ez 18, 21-28; Róm 11,22k; 1Kor 9,27; Mt 7,13k). Az isteni szuverenitás és az emberi szabadság között feszülő ellentét csupán látszólagos, hiszen mind Isten kegyelme, mind az ember szabad engedelmessége szükséges az üdvösséghez. „Pál igazolódni látja ezt saját életében (Csel 22,6-10; 1Kor 15,10), de az összes keresztény életében is Fil 2,12k). Isten azonban ismeri annak titkát, hogy miként térítheti meg szívünket erőszak nélkül, s miként vonhat minket magához kényszere nélkül (vö. Zsolt 119,36; Ez 36,26k; Óz 2,16k; Jn 6,44)." Léon Roy: Megszabadítás/Szabadság. Szócikk. In Xavier Léon-Dufour et alii (szerk.): Biblikus teológiai szótár. Budapest, Szent István Társulat, 1986. 910-917.911.

56 Isten megszabadította a népet Egyiptom szolgaságából (Kiv, 1-15), s erre a szabadításra minduntalan visszautal az Írás. „Társadalmi síkon magát a bibliai törvényhozást is Izrael első megszabadulásának emléke hatja át, főként a deuteronomista áramlatban: a héber rabszolgát a hetedik évben fel kellett szabadítani annak emlékére, amit Jahve cselekedett övéivel (MTörv 15,12-15; vö. Jer 34,8-22). A törvényt különben nem mindig tartották meg, és Nehémiásnak még a száműzetésből való visszatérés után is fel kellett emelnie szavát bizonyos honfitársai pénzéhsége ellen, akik nem haboztak rabszolgaságra vetni a »kiváltott« testvéreiket (Neh 5,1-8). Ezért szabadon bocsátani a megtörteket, összetörni minden igát, íme, ez az a fajta »böjt, amelyet Jahve kedvel« (Iz 58,6)." Uo. 914.

57 Krisztus, a mi megszabadítónk. Izrael megszabadítása csupán előképe volt a keresztény megváltásnak. A tökéletes és végérvényes szabadság uralmát ugyanis Krisztus teremti meg azoknak, zsidóknak és pogányoknak, akik csatlakoznak hozzá a hitben és a szeretetben. L. uo. 914. „Ha tehát a Fiú szabaddá tesz titeket, akkor lesztek valóban szabadok" (Jn 8,36).

58 „Bár a keresztény szabadságnak szociális értelemben igen nagy a hordereje - amiről a Filemonnak írt levél tanúskodik ragyogóan -, mégis fölébe emelkedik a társadalomnak. Mivel rabszolga és szabad egyaránt szert tehet rá, nem kíván meg állapotváltozást (1Kor 7,21). Ez a tény paradoxonként hatott a görög-római világban, ahol még a méltóságnak is a polgári szabadság adta meg az alapját; így vált azonban nyilvánvalóvá a Krisztus által felajánlott megszabadítás alapvetőbb értéke." Roy i. m. (55. lj.) 914. A hívő abban az értelemben szabad, hogy Krisztusban immár módjában áll bensőséges kapcsolatban együtt élni az Atyával anélkül, hogy megbéklyóznák a bün, a halál vagy a törvény kötelékei. A keresztség Krisztus halálában és feltámadásában részesített, és ezzel véget vetett szolgaságunknak (Róm 6,6). „Isten kiragadott minket a sötétség hatalmából, és áthelyezett szeretett Fia országába. Benne nyertük el a megváltást, bűneink bocsánatát” (Kol 1,13k). Meghaltunk Krisztussal, és ezért felszabadultunk a törvény alól (Róm 7,1-6), és üdvösségünk elvét többé nem kereshetjük külső törvény teljesítésében ( $\mathrm{Gal} 3,2-13 ; 4,3 \mathrm{kk})$. Új rendszerben élünk, amelynek zsinórmértéke is más (Jer 31,33; Ez 36,27; Róm 5,5; Róm 8,9-14; 2Kor 3,3-6).

59 A keresztény Isten előtt fiúként viselkedik (Ef 3,12; Zsid 3,6; Zsid 4,16), mert a keresztségben nem a szolgaság lelkét kapta, hanem a „fogadott fiúság lelkét” (Róm 8,14-17).

60 „Minden szabad nekem, de nem minden hasznos” - szögezi le az apostol (1Kor 10,23). Ez a kijelentés utal a mértéktartás, az önmegtagadás, a mások iránti felelősségvállalás, a minket megillető jogokról való lemondás (1Kor 8-10; Róm 14), a bölcs belátás, az isteni üdvterv szerinti gondolkodás, végső soron pedig a szeretet szükségességére. Akkor sem tévedünk nagyot, ha a kísértő helyzetek kerülésére vonatkozó józan elvárást látunk a mondatban. Mindezek nem a szabadság korlátozásai, hanem magasabb fokon történő gyakorlásának formái. A rabszolgaságukból Isten szolgálatára kiváltott keresztények (Róm 6) megbecsülik a kapott ajándékot, szeretettel szolgálnak egymásnak (Gal 5,13) és másoknak, amint a lélek vezeti őket (Gal 5,16-26). 
szántaknak a feltámadás reményét, az Istennel való közösség végleges helyreállítását ígéri. A szabadság azonban Jézus szerint nem öncél, azt minden esetben hozzákapcsolja Isten igazságához és/vagy szeretetéhez (kegyelméhez), az ezekben való növekedéshez.

E szabadság nem lehet többosztatú. Ha egyes vonatkozásait próbáljuk kiemelni s önállóan elemezni, hamar eljutunk egy látszólagos ellentmondáshoz: egyes aspektusok kifejezetten radikális, erőteljes, a mindenkori konvenciókkal leszámoló képet festenek a keresztény szabadság természetéről, míg mások a gyengéd és visszafogott, egyenesen önfeladó elemeket hangsúlyozzák. A kettő nem egymást kizáró elem, sőt a kettő csak együtt eredményezhet egy egészséges szabadságfogalmat és annak megfelelő gyakorlati alkalmazást. Hermann Pitters ezt a következőképpen fogalmazza meg:

„Luther A keresztény ember szabadságáról írt munkájában, mely 1520-ban jelent meg, [...] megállapítja: »A keresztény ember szabad minden dolog felett, és semminek sincs alávetve«. Ez a szabadság a hitben tapasztalható meg. Akit Isten a hitben az ő ajándékozó kegyelmével megragadott, az a szabadság fenséges, széles területét birtokolja. De a második kijelentése is éppen ennyire igaz: »A keresztény ember minden dologban szolgálatra kész szolga és mindenkinek alá van vetve« a szeretet által. A felebarát szeretete tekintettel van a többi emberekre is és kész minden jónak szolgálatára." ${ }^{61}$

A keresztény szabadság e kettős természetének figyelmen kívül hagyása és az egyik végpont hangsúlyozása már Martin Luther idejében (is) félreértelmezéseket eredményezett: a szabadság radikális felfogása ugyanis egymagában könnyen megfeledkezik a szeretetről, a gyengékről való gondoskodás szükségletéről, s forradalmi programmá válva kiiktatja az önmegtagadást és általában az önérdek ellenében érvényesülő készségeket. ${ }^{62}$ Innen pedig már csupán egyetlen lépés a politikai (ön)cél vallási köntösbe bújtatása. Jézus idejében (is) sok zsidó „kétségtelenül főként azt várta, hogy [Jézus] felszabadítja a Szentföldet a pogányok által rárakott iga alól, és ezért történhetett, hogy az emmauszi zarándokok is így képzelték el annak feladatát, aki „meg fogja váltani Izraelt" (Lk 24,21) ${ }^{63}$ Fontos azonban, hogy Jézus programja nem egy fizikai ellenállásban testet öltő, politikai program, hanem egy nem kevésbé radikális, lelki típusú harc, illetve „szabadítás”, amit a Zsolt 130,8 juttat kifejezésre: „Ő megszabadítja Izraelt minden gonoszságától.” Az igazi megszabadulás ugyanis a meghívást kapottak megtisztulása, Isten szentségében való részesedése már akkor is (vö. Iz 1,27; 44,22; 59,20), és azóta is. ${ }^{64}$

61 Hermann Pitters: Luther Márton - a keresztény szabadság hirdetője. Gondolatok a reformátor születésének 500. évfordulóján Keresztény Magvetö, 89. (1983), 4. 239-245. 241.

62 Uo. Pitters konkrét negatív példaként Karlstadtnak, a wittenbergi teológiai fakultás tanárának 1522es, az indulatok elszabadulását eredményező külső egyházi reformkezdeményezését hozza fel.

63 Roy i. m. (55. lj.) 913.

64 Uo. 
A fentiekből is jól kimutatható önzés - földi célok és önmegtagadás - lelki célok kettősség kapcsán Pierre Teilhard de Chardin jegyzi meg, hogy „[a] Krisztussal való egyesülés föltételezi, hogy létezésünk végső központját Belé helyezzük, - ez pedig az önzés gyökeres feláldozását jelenti. [...] Hogy Krisztus az én egész életemet - az egész életet - hatalmába vegye, ehhez föltétlenül szükséges, hogy én növekedjem Benne nemcsak aszkétikus önmegtagadásokkal és a szenvedés okozta nagyszerüen egyesítő elszakadásokkal, hanem mindazzal is, ami pozitív erőfeszítést jelent és természetesen tökéletesíti létezésemet." 65

Teilhard de Chardin gondolata is arra ösztönöz minket, hogy a keresztény szabadságot ne csupán statikus elemek egymásmellettiségeként, még kevésbé egyetlen aspektusra kihegyezett fogalomként jelenítsük meg, hanem a szabadság kifejlődését próbáljuk meg folyamatában is megragadni, ezzel is (fel)oldva a statikus állítások révén keletkező feszültséget, azok látszólagos ellentmondását. Azt látjuk, hogy e kérdéskör, illetve fogalom is könnyebben megragadható és bemutatható egy folyamatszerü, egymásra reflektáló és egymásra épülő elemekből álló rendszerben. Azt feltételezzük, hogy a szabadsághoz való viszonyunk is - különösen keresztényként - egy kiteljesedő, terebélyesedő tudás, illetve tényleges praxis, s e tanulmányban kísérletet teszünk ennek a folyamatnak rövid áttekintésére is egy hatelemü, dinamikus modell felkínálásával.

E megközelítés lehetőségét erőteljesen alátámasztja az, hogy csak az Újszövetségben számos példát látunk erre a megközelítésre, azaz az Istennel való kapcsolat kiépülésének folyamatszerủ leírására. A 2Pt 1,5-7 például a következőképpen mutatja be ezt a processzust: „Éppen ezért teljes igyekezettel törekedjetek arra, hogy hitetekben mutassátok meg az igaz emberséget, az igaz emberségben ismeretet, az ismeretben önuralmat, az önuralomban állhatatosságot, az állhatatosságban kegyességet, a kegyességben testvéri szeretetet, a testvéri szeretetben pedig minden ember iránti szeretetet." Tehát fejlődésről, egymásra épülő lépésekről, növekedési fázisokról, egy egyértelmű érési folyamatról van szó. Ugyanígy, a Biblia egyik legismertebb részében, a Mt 5,3-12-ben is egy kiteljesedő karaktert látunk a boldogságmondások egymásutániságában is, azaz nem csupán véletlenszerủen egymás mellé helyezett „bölcs mondások" gyüjteményéről van szó: ${ }^{66}$ a nyomasztó lelki szükséglet észlelése után annak érzelmi átélése (felvállalása), majd a harag és frusztráció helyett az azzal való alázatos szembenézés következik. Az ily módon kialakult lelki nyitottság révén válhatunk

65 Pierre Teilhard de Chardin: Benne élünk (Az Isteni Miliö). Tanulmány a belső életröl. Párizs-Bécs, Ahogy Lehet, 1967. 74.

66 „Boldogok a lelki szegények, mert övék a mennyek országa. Boldogok, akik sírnak, mert ők megvigasztaltatnak. Boldogok a szelídek, mert ők öröklik a földet. Boldogok, akik éheznek és szomjaznak az igazságra, mert ők megelégíttetnek. Boldogok az irgalmasok, mert ők irgalmasságot nyernek. Boldogok a tiszta szívűek, mert ők meglátják Istent. Boldogok, akik békét teremtenek, mert ők Isten fiainak neveztetnek. Boldogok, akiket az igazságért üldöznek, mert övék a mennyek országa. Boldogok vagytok, ha énmiattam gyaláznak és üldöznek titeket, és mindenféle rosszat hazudnak rólatok. Örüljetek és ujjongjatok, mert jutalmatok bőséges a mennyekben, hiszen így üldözték a prófétákat is, akik előttetek éltek." 
fogadókésszé az igazságra (arra, hogy mit is kell tenni), majd pedig a helyes cselekvés gyakorlása révén az ember alkalmassá lesz a legnehezebb dologra: a másiknak való megbocsátásra is. $\mathrm{S}$ ha a fejlődés e pontján sem terít le minket a vallásos büszkeség („milyen klassz is vagyok”), akkor a tiszta szív indulata hálává sűrűsödik, és mindenkinek erről akar beszélni, megkísérelve az Isten-ember és ember-ember kapcsolatok helyreállítását is (ez a béketeremtés szolgálata). Végül pedig ez a Krisztusban meggyökeredzett és kiteljesedett élet, az Isten melletti kiállás szinte szükségképpen idézi elő az üldöztetést...

\subsection{A keresztény szabadság dinamikus fogalma}

Az alábbiakban tehát arra teszünk kísérletet, hogy a keresztény szabadság fogalmát is folyamatszerűen ábrázoljuk egy lelki előrehaladás stációin keresztül. Eme dinamikus fogalomalkotás melletti érv egyfelől az a tény, hogy az egyén szubjektív szabadságészlelése szükségképpen folyamatszerủ, amennyiben azt felismerések, tudatosuló igények, külső-belső küzdelmek, fejlődő meggyőződések alakítják, másfelől mindeme változásnak van egy egyértelmű idődimenziója is, azaz az egyén letisztult, saját használatú szabadságfogalma csak egy hosszabb időintervallumban bontakozhat ki. Mindezen szempontok mellett azt is feltételezzük, hogy az egyes állomások valamilyen mértékben egymásra épülnek, sőt azok sorrendisége is - legalább részben - kötött. Jelen munkában hat ilyen lépcsőfokot, egymásra tekintettel rendszerbe illeszthető szabadságelemet különböztetünk meg, szükségesnek ítélve ezek későbbi pontosítását, kiegészítését, árnyaltabb kibontását, sőt az egyes elemek további egynemüsítését is...

1. fázis: Isten megismerésének szabadsága. Ebbe beletartozik az üdvterv lényegének megismerhetőségén túl magával a szabadsággal kapcsolatos, Isten által kinyilvánított tudáshoz való hozzáférés lehetősége, szabadsága is. A keresztény szabadság alapja, kiindulópontja annak szabadsága, hogy valaki a helyes ismeret szerint megismerje Isten személyét és akaratát (szándékait). Isten szabadon megismerhetővé teszi önmagát ${ }^{67}$ kényszerek nélkül hajlamosítva minket a vele való közösségre, azokról is körültekintően gondoskodva, akikhez valamilyen oknál fogva nem jut el a róla szóló tanítás. ${ }^{68}$

2. fázis: Isten ember általi választásának a szabadsága. Szükséges egy első intellektuális döntés, amit aztán sok további gyakorlati követ, konkrét, nehézkesebb helyzetekben is. Trivialitás, de lényeges: a szeretet nem elsősorban érzés, sokkal inkább - különösen hosszabb távon - meggyőződésre alapozott döntés, bármely kapcsolattípusban. Az Istennel való kapcsolat is ilyen: jó és segítséget jelent, ha vannak

67 A Biblia alkalmas a valódi szabadság lényegének és Isten természetének megértésére (Róm 1,19-20; továbbá 2Tim 3,16: „A teljes Írás Istentől ihletett, és hasznos a tanításra, a feddésre, a megjobbításra, az igazságban való nevelésre"), közvetlen, személyes tanulmányozása és közvetett, más általi hirdetése révén is megalapozva a hitet (Róm 10,17). 
forró és hálával teli stb. érzések is az emberben, például a sikeres „keresés” ${ }^{69}$ nyomán előálló ujjongó érzések formájában, de a kapcsolat tartósságához feltétlenül kellenek a helyes meggyőződések is. Erre a fázisra - túltekintve az első elköteleződés mozzanatán vagy mozzanatain - úgy is tekinthetünk, mint a fiatal, „első szeretettel” bíró keresztény magatartására. Ez feltétlenül a frissesség fázisa, az Istennel való közösség felszabadultságának megélt öröme. Ekkor az egyéni döntés és magatartás a hangsúlyos, domináns az egész szituációban, a felmerülő helyzetek mindegyikében.

A körülmények ekkor másodlagosnak tűnnek: az első szeretet lendülete révén a keresztény a természeti törvények ellenében, a vallási hagyomány ellenében, sőt a saját maga által korábban követett szabályok ellenében is szabadon szárnyal... Nem feszélyezi, hogy olyasmit tegyen, aminek látszólag semmilyen világi haszna, értelme nincs, ami a világ logikája szerint egyenesen értelmetlen. Belülről hajtja az öröm, amely a Jézussal való kapcsolatát is elmélyíti, s mindeközben „bolonddá” lesz: „[m]ert a keresztről szóló beszéd bolondság ugyan azoknak, akik elvesznek, de nekünk, akik üdvözülünk, Istennek ereje" (1Kor 1,18). Ez a korlátlan bizalom szakasza is, azaz a látható és fizikailag megtapasztalt dolgok ellenében való elszántság ideje: „Simon így felelt: Mester, egész éjszaka fáradoztunk ugyan, mégsem fogtunk semmit, de a te szavadra mégis kivetem a hálókat” (Luk 5,5). Mindez az Ószövetségben így hangzott: „Aztán hozzád kiáltunk szorongattatásainkban, s akkor te meghallgatsz és megsegítesz bennünket" (2Krón 20,9b). Sőt ugyanott, a 12b vers is megmutatja, hogy mit is jelent a teljes odafordulás, a bizonytalanságok közepette is tökéletes bizalom: „Nem is tudjuk, mit kellene tennünk, csak a tekintetünk emeljük hozzád." Ez tehát az elköteleződés szabadsága.

3. fázis: Az érett kereszténység fázisa: az első szeretet visszaszerzésének ciklikus jelensége. Ez a meggyőződések elmélyülésének és az első szeretetre jellemző attitűdök tudatos visszaszerzésének szakasza (keresztény életszakasza). A harmadik fázis (vagy összetevő, aspektus stb.) hangsúlyait tekintve a megállapodott, érett, stabil közösségen belüli kereszténység logikája, illetve szabadsága. A közösségen belüli fokozott felelősségvállalás önkéntes („szabad”) gyakorlásának mint szükségszerűségnek a felismerése kíséri. Annak felmérése és gyakorlati megvalósítása, hogy kitartani, keresztényként megújulni, a kísértések és elbukások ellenére is talpra állni csak élő, Krisztusban meggyökeredzett közösségben lehet. Legplasztikusabban az Újszövetség „egymás” idézetei mutatják meg, hogy mit, mi mindent is jelent ez a hétköznapok sodrásában, a megerősödés iránti, erősödő szükséglet idején. ${ }^{70}$

69 ApCsel 17,26-28: „Az egész emberi nemzetséget egy vérből teremtette, hogy lakjon az egész föld színén, meghatározta elrendelt idejüket és lakóhelyük határait, hogy keressék az Istent, hátha kitapinthatják és megtalálhatják, hiszen nincs messzire egyikünktől sem, mert őbenne élünk, mozgunk és vagyunk."

70 „Egymást kitartóan, tiszta szívből szeressétek.” (1Pt 1,22); „A testvéri szeretetben legyetek gyöngédek egymáshoz, a tiszteletadásban előzzétek meg egymást” (Róm 12,10); „Karoljátok fel tehát egymást, amint Krisztus is felkarolt benneteket Isten dicsőségére” (Róm 15,7); „Hordozzátok egymás terhét, így tejesítitek Krisztus törvényét. Aki beképzeli magának, hogy valaki, holott senki, önmagát áltatja” (Gal 6,2-3); „Valljátok meg azért egymásnak büneiteket, és imádkozzatok egymásért, hogy 
A döntések - mindamellett, hogy továbbra is egyéniek kell, hogy legyenek - közösségi dimenziójúvá válnak, már csak azért is, mert a világ „szívó hatása” rendkívül nagy: „Azt mondom tehát, sőt figyelmeztetlek titeket az Úrban, ne éljetek úgy, mint a pogányok, akik hiúságokon járatják az eszüket. Sötétség borult elméjükre és elidegenedtek az istenes élettől tudatlanságukban, amely szívük megátalkodottságának következménye. Lelkileg eltompulva kicsapongásra adták magukat és kapzsiságból mindenféle ocsmányságot üznek" (Ef 4,17-19). Nem véletlenül hangzik el különféle formákban újra és újra: „A szabadságot Krisztus szerezte meg nekünk. Álljatok tehát szilárdan, és ne hagyjátok magatokat újra a szolgaság igájába hajtani..." (Gal 5,1). ${ }^{71}$ A mértéktartás, bölcs (érett) önkorlátozás szükségessége ott is felmerül, ahol egyébként még nem került sor „határátlépésre” vagy nyilvánvaló elbukásra, csupán egy lelki sodródás folyamata indult el, s még időben érdemes visszahőkölni. ${ }^{72}$

E letisztultabb szabadságkoncepciónak része azonban a vélemény szabadsága is mindazon kérdésekben, amelyek hétköznapi kérdésekben eredményeznek különbséget (milyen ételeket szeretek, ki a kedvenc íróm stb.), illetve azon vallási (teológiai) kérdésekben is, amelyek nem a hit alapkérdéseihez tartoznak (nem megváltáskérdések), így - adott esetben - a kényes lelkiismeretűek iránti tolerancia körébe sorolhatók. Miközben a keresztény növekszik az ismeretben és a valódi szeretetben, emberi testben soha nem válik tökéletessé, ha nő is a másokra figyelésben stb., szükségképpen hibázni fog, így szükséges a következő fázis is, a szabadság újabb köre.

4. fázis: A hibázás szabadsága. A kereszténység legnyomorúságosabb formája az, amely csupán a szabályok betartására, az igazság szerinti életre koncentrál, s amely szavakban elismeri ugyan önnön tökéletlenségét, de gyakorlataiban elkendőzné legtöbb gyengeségét: ez az attitüd egyéni és közösségi életmóddá válva szükségképpen képmutatást és vallásos felszínességet eredményez, végső soron pedig rideg szabálykövetést, s állandó elégedetlenséget. Végső soron a kegyelem természetéről, annak megértéséről szól ez a 4. alpont, arról, hogy e nélkül elvész a halálon felülkerekedő élet öröme, a szeretet igazsággal birokra kelő hatalma, s minden más is, ami élővé teheti az ember hitét.

Jól példázza az eddig elmondottakat az a felvetés, hogy bízzunk meg egy jogászt a megtérés bibliai fogalmának kimunkálásával. Jó eséllyel hamar össze is állítana bármelyik olvasni és szöveget valamennyire is értelmezni tudó jogász egy háromelemü fogalmat, amely szerint a megtérés (már keresztényként) egyrészt a szívbéli megszomorodás, az elkövetett tettől való érzelmi és tudati elhatárolódás, „méltatlankodás" mozzanatából, másrészt a bűn megvallásából (Isten, illetve emberek elé vitelé-

meggyógyuljatok. Nagy az ereje az igaz ember buzgó könyörgésének” (Jak 5,16); „Viseljétek el egymást, és bocsássatok meg egymásnak, ha valakinek panasza van a másik ellen. Ahogy az Úr megbocsátott nektek, ti is bocsássatok meg egymásnak" (Kol 3,13) stb.

71 Ld. még Gal 4,26-31; 1Kor 7,22; 2Kor 3,17.

72 „Jézus ezt mondta neki: Viszont meg van írva: „Ne kísértsd az Urat, a te Istenedet!«” (Mt 4,7); „Aki tehát azt gondolja, hogy áll, vigyázzon, hogy el ne essék!” (1Kor 10,12); „Mert ti, testvéreim, szabadságra vagytok elhívva; csak a szabadság nehogy ürügy legyen a testnek, hanem szeretetben szolgáljatok egymásnak" (Gal 5,13). 
ből), harmadrészt pedig a materiális következmények elhárításából (jóvátételből) áll. Ha elfogadjuk ezt a „munkafogalmat”, akkor a legtökéletesebb megtérés Júdásé lesz, aki - amint azt az Îrás is rögzíti - megbánta tettét, megvallotta azt a vezetőknek, $\mathrm{s}$ a kapott vérdíjat is „visszaadta”... ${ }^{73}$ Mégsem látjuk őt a többiekkel később, sőt, azt olvassuk, hogy öngyilkos lett. De miért, ha minden emberit elkövetett, hogy helyrehozza a hibáját? S ezen a ponton lép be a képbe - esetünkben a válaszba - a kegyelem kérdése: Júdás ugyanis egy dolgot nem tudott megérteni, felfogni, elfogadni, azt, hogy számára is létezik megbocsátás, hogy akár Jézus - ha még időben utánaered -, akár a többi tanítvány megbocsátana neki. Nem értette a kegyelem lényegét, a földi logikák ellenében megmutatkozó, igazságon is túlmutató szeretet természetét, a megbocsátás isteni logikáját.

A megbocsátás magamnak és a másiknak, avagy másként, a kegyelem megértése és gyakorlása tehát a szabadság következő foka. Látszólagos paradoxonként az, hogy az igazságot saját döntéseinkben is szabadon ki merjük egészíteni a kegyelemmel, csak az „igazság” pontosabb megértésének lehet a következménye (a 69. lábjegyzetben már megjelenik a közösségben gyakorolt megbocsátás szükségessége mint olyan magatartás, amely nélkül nincs továbblépés - lelki értelemben).

5. fázis: Isten döntési szabadsága. Isten döntési szabadsága (mint a keresztény szabadság elvitathatatlan eleme) alatt azt értjük, hogy az élet legeslegfontosabb dolgaiban vannak biztos igazságok (megkerülhetetlen fizikai és/vagy hitbéli tények), de a reánk váró dolgok egy jelentős részét nem látjuk előre: azok jellegét, idejét nem tudjuk előre megbecsülni, prognosztizálni. Ez a „kiszolgáltatottság” a keresztény szabadság legizgalmasabb, s egyúttal legtöbb alázatot is igénylő aspektusa. Elfogadni a váratlant, a nemkívánatost, az érzéseinket, igazságérzetünket stb. feszélyezőt, sértőt... nehéz. Elfogadni a betegséget, a most is tomboló Covid-19 koronavírus-járványt, annak következményeit - szintén nehéz.

Létünknek ezt a kötöttségét, „beszorítottságát” Teilhard de Chardin úgy fejezte ki, hogy „[a] "passzivitások“ (adottságok) az emberi létezés felét alkotják. Ez a kifejezés egészen egyszerủen csak azt akarja mondani, hogy amit nem mi önmagunk cselekszünk, az - a meghatározás szerint: szenvedőleges, vagyis más cselekszi azt mirajtunk. [...] Mindenekelött: tudatos tetteinket szüntelenül kísérik az adottságok, mint erőfeszítéseinket irányító, fenntartó vagy meghiúsító reakciók.”74 Márpedig ezen „passzivitások" közepette nem könnyủ hit által bízni az ígéretekben: abban például, hogy Isten nem kísért a rosszra,${ }^{75}$ hogy nem terhel meg erőn felül, ${ }^{76} \mathrm{~s}$ hogy mindent - valóban mindent - a javamra fog használni, ha őt, az ő akaratát keresem az életemben. ${ }^{77}$ Ám ez a bizalom egyúttal perspektívát is nyit, a nagy képet, annak kontúrjait

73 Mt 27,3-5.

74 Teilhard de Chardin i. m. (65. lj.) 52.

75 Jak 1,13 .

76 Kor 10,13 .

77 „Azt pedig tudjuk, hogy akik Istent szeretik, azoknak minden javukra szolgál, azoknak, akiket elhatározása szerint elhívott" (Róm 8,28). 
tovább pontosítja bennem, s segíthet még valóságosabbnak látnom a mennyországot is, amely a következő „stáció” is egyúttal.

Összefoglalva: Isten döntési szabadságának helyes értelmezése annak felmérését és elfogadását jelenti, hogy noha magukat az eseményeket egyáltalán nem vagy csak korlátozottan tudom befolyásolni, az eseményekhez való viszonyulásom az én döntésem (erre vonatkozóan igenis van szabadságom). Tágabb lelki perspektívában ez azt is jelenti, hogy nem csupán mindezek tudomásul vételére van lehetőségem: szabadon élvezhetem, sőt örömtelien élhetem meg azt a helyzetet, hogy én ültethetek, öntözhetek, de a növekedés nem tőlem van. ${ }^{78}$ Azt, hogy én csupán munkatárs vagyok, de immár nem szolgaként, hanem fiúként, illetve barátként lehetek részese Isten munkájának.

6. fázis: A mennyország szabadsága - az élet nagyobb részének Isten közvetlen jelenlétében való eltöltése. Az előbbi szakaszok (fázisok) megélése, „interiorizálása”, azaz Isten személyének és életemre irányuló tervének cselekvésben is megnyilvánuló elfogadása szükségképpen fordítja figyelmemet a jövő ígérete felé is. A jövő döntő részét (a létem fizikai, testi formán túli részét) adó mennyország felé, amely egy csodálatos hely. A Biblia azt mondja: „Amit szem nem látott, fül nem hallott, és ember szíve meg sem sejtett, azt készítette el Isten az őt szeretőknek" (1Kor 2,9b). Istennek van egy tökéletes terve számunkra, aminek a menny is része - ez is nekünk van tervezve. Nagyon is konkrétan a következőket olvassuk a mennyről: „Mivel egy új életre támadtatok fel a Krisztussal, a menny valóságos dolgaira szegezzétek tekinteteteket, ahol a Krisztus a dicsőséges helyen, az Isten jobbján ül” (Kol 3,1). Krisztus pedig nem csupán ott ül, de aktív módon vár minket: „Atyám házában sok hajlék van. Ha nem így volna, mondtam volna nektek, hogy elmegyek helyet készíteni nektek? Azért megyek el, hogy helyet készítsek nektek” (Jn 14,2-3). Erre utal a 2Kor 5,1 is: „Tudjuk ugyanis, hogy ha ez a mi földi sátrunk leomlik, Istentől kapunk hajlékot, nem kézzel alkotott, örök házat az égben." Ez tehát a keresztény szabadság kiteljesedésének utolsó fokozata, lépcsőfoka, amely által a teológiai megközelítésű, ám dinamikus természetű fogalmunk utolsó eleme is a helyére került.

\section{5. Összefoglalás}

A keresztény szabadság legizgalmasabb összefüggéseinek bemutatását több (tudomány)terület szemszögéből is megkíséreltük elvégezni. Újdonságot a dinamikus, folyamatszerű megközelítések jelentettek, mind a jogi, mind pedig a teológiai vizsgálat esetében. Az előbbi esetben ez bizonyult célszerűnek, amennyiben a normatív és egyedi jogforrások tartalmán túlmutató, a valóságot precízebben bemutató, (jog) szociológiai elemzés révén alkothatunk pontosabb fogalmat a jogéletről szűkebb témánk kapcsán is, míg az utóbbi esetben azt jeleztük, hogy a statikus elemek ellenében egy kialakuló, fejlődésében megragadható emberi karakter természetes(ebb) közegét

78 1Kor 3,6. 
jelenti a vizsgálatnak - ugyancsak pontosabb fogalmat eredményezve. Természetesen el kell ismernünk, hogy éppen a fogalmi alapozás kezdetlegessége, kísérleti volta okán további vizsgálatok, alaposabb elemzések állnak előttünk, miközben reméljük, hogy e tanulmány megállapításai mások kutatásaira is élénkítőleg hatnak majd, akár a keresztény szabadság további vizsgálatai során, akár pedig más témákban, ahol is szintén a dinamikus, folyamatszerű megközelítések alkalmazása látszik indokoltnak.

\section{Irodalomjegyzék}

Borbás Barna: „Trón és oltár”: míg a keresztény szabadságon rágódunk, kiürülnek a templomaink. Válasz Online, 2019. október 24. Elérhető: www.valaszonline.hu/2019/10/24/politikai-keresztenyseg-keresztenydemokracia-vita/ (A letöltés dátuma: 2020.09. 29.)

Cherribi, Sam: Bad Faith: The Danger of Religious Extremism by Neil J. Kressel. Review. Political Psychology, 30. (2009), 2. 319-323. DOI: https://doi.org/10.1111/j.1467-9221.2008.00693.x

Daniel, Krystyna - Durham, W. Cole: A vallási azonosságtudat, mint a nemzeti identitás összetevője. Fundamentum, 1. (1997), 2. 5-21.

Escobar, Arturo: Latin America at a Crossroads: Alternative Modernizations, Post-Liberalism, or Post-Development? Cultural Studies, 24. (2010), 1. 1-65. DOI: https://doi. org/10.1080/09502380903424208

Formicola, Jo R.: Recalibrating U.S. Catholic Church-State Relations: The Effects of Clerical Sexual Abuse. Journal of Church E State, 58. (2016), 2. 307-330. DOI: https://doi.org/10.1093/ jcs/csu108

Iannaccone, Laurence R.: Religious Extremism: Origins and Consequences. Contemporary Jewry, 20. (1999), 1. 8-29. DOI: https://doi.org/10.1007/BF02967957

Kasper, Walter (szerk.): Zukunft aus der Kraft des Konzils. Die ausserordentliche Synode '85. Freiburg, Herder, 1986.

Köbel Szilvia: Az Alkotmánybíróság vallásszabadsággal és vallási közösségekkel kapcsolatos gyakorlata. In Köbel Szilvia (szerk.): Az állami és a felekezeti egyházjog alapjai. Budapest, Patrocinium, 2016. 207-234.

Lánszki Béla: A felszabadítási teológia ideje lejárt? Credo, 5. (1999), 3-4. 69-75.

Lukács László: A keresztény szabadság politikai dimenziói a felszabadítási teológia tükrében. Sapientiana, 7. (2014), 2. 1-31.

McPhillips, Kathleen: The Church, the Commission and the Truth: Inside the NSW Special Inquiry into Child Sexual Abuse. Journal for the Academic Study of Religion, 29. (2016), 1. 30-51. DOI: https://doi.org/10.1558/jasr.v29i1.27305

Ormóshegyi Zoltán - Rixer Ádám: Magyarországi vallási közösségek pénzügyi forrásai és gazdálkodása a jogi szabályozás tükrében. In Köbel Szilvia (szerk.): Az állami és a felekezeti egyházjog alapjai. Budapest, Patrocinium, 2016. 176-207.

Pitters, Hermann: Luther Márton - a keresztény szabadság hirdetője. Gondolatok a reformátor születésének 500. évfordulóján. Keresztény Magvetö, 89. (1983), 4. 239-245.

Pressing Lajos: A deviancia és a vallás kapcsolata. In Münnich Iván - Moksony Ferenc (szerk.): Devianciák Magyarországon. Budapest, Közélet, 1994. 201-222.

Ratzinger, Joseph: Beszélgetés a hitrôl Vittorio Messorival. Budapest, Vigilia, 1990.

Rixer Ádám: A vallás fogalmáról. Jogelméleti Szemle, 12. (2011), 4. 1-8. 
Rixer Ádám: A hatásvizsgálatok jelentősége és egyes szempontjai a vallási szervezetek szabályozása körében. Kodifikáció, 2. (2013), 1. 91-102.

Rixer Ádám: A történeti alkotmány vívmányai: Utazás a múltba vagy út a jövőbe? In Balogh Judit et alii (szerk.): 65. Studia in honorem István Stipta. Budapest, KGRE ÁJK, 2017. 365-375.

Rixer Ádám: Az állam és a vallási közösségek kapcsolata a mai Magyarországon. A vallási közösségek nyilvántartása és pénzügyei a jogi szabályozás tükrében. Államtudományi Mühelytanulmányok, 2. (2017), 1. 1-45.

Rixer Ádám: A vallási szélsőségek tipológiája Magyarországon. Vallástudományi Szemle, 14. (2018), 4. 15-30.

Rixer Ádám: A Biblia szövegeinek felhasználhatósága az egyházi fenntartású intézmények belső dokumentumaiban. In Birher Nándor - Homicskó Árpád Olivér (szerk.): Az egyházi intézmények müködtetésének etikai alapjai. Budapest, KGRE ÁJK, 2019. 25-36.

Rixer Ádám: A civil társadalom helyzete Magyarországon, különös tekintettel a populizmus térnyerésére. Glossa Iuridica, 6. (2019), 3-4. 43-72.

Rosetti, Stephen J.: Bátor szembenézés: Hatékony fellépés a gyermekek szexuális kihasználóival szemben. Korunk, 23. (2012), 4. 99-106.

Schanda Balázs: Állami egyházjog. Vallásszabadság és vallási közösségek a mai magyar jogban. Budapest, Szent István Társulat, 2012.

Schanda Balázs: Magyarország keresztény kultúrájáról. Pázmány Law Working Papers, 2018/8. 1-4.

Tajti Enikő: Otthon a világban. A konformizmus és non-konformizmus teológiai értelmezése Róma 12:1-2 és János 4. rész értelmében. Szakdolgozat. Budapest, Baptista Teológiai Akadémia, 2018.

Teilhard de Chardin, Pierre: Benne élünk (Az Isteni Miliő). Tanulmány a belső életről. Párizs-Bécs, Ahogy Lehet, 1967.

Tuskhova, Julia V.: ISIS and Al-Qaeda as the Determinants of Religious Extremism in the UK. Society: Politics, Economics, Law, 14. (2017), 8. 1-4.

Uitz Renáta: Lelkiismereti és vallásszabadság a multikulturális Európában. Hogyan tovább? Hova tovább? Jogtudományi Közlöny, 74. (2019), 5. 213-228.

Weaver, Russell L.: Szólás- és vallásszabadság az Amerikai Egyesült Államokban. Budapest, Wolters Kluwer, 2019. 